\title{
An integrated energy performance-driven generative design methodology to foster modular lightweight steel framed dwellings in hot climates
}

\author{
Eugénio Rodrigues $^{\mathrm{a}, \mathrm{b}, *}$, Nelson Soares ${ }^{\mathrm{a}, \mathrm{c}}$, Marco S. Fernandes $^{\mathrm{a}}$, \\ Adélio Rodrigues Gaspar ${ }^{\mathrm{a}}$, Álvaro Gomes ${ }^{\mathrm{b}, \mathrm{d}}$, José J. Costa ${ }^{\mathrm{a}}$ \\ ${ }^{a}$ ADAI, LAETA, Department of Mechanical Engineering, University of Coimbra \\ Rua Luís Reis Santos, Pólo II, 3030-788 Coimbra, Portugal \\ ${ }^{b}$ INESC Coimbra - Institute for Systems Engineering and Computers in Coimbra \\ Rua Silvio Lima, Pólo II, 3030-290 Coimbra, Portugal \\ ${ }^{c}$ ISISE, Department of Civil Engineering, University of Coimbra \\ Rua Luís Reis Santos, Pólo II, 3030-788 Coimbra, Portugal \\ ${ }^{d}$ Department of Electrical and Computer Engineering, University of Coimbra \\ Rua Sílvio Lima, Pólo II, 3030-290 Coimbra, Portugal
}

\begin{abstract}
This paper presents a study on the application of lightweight steel framed (LSF) construction systems in hot climate. A generative design method created 6010 houses, with random geometry and random roof and exterior wall types with different insulation levels, and EnergyPlus was used to evaluate the energy consumption for air-conditioning of each building. The main goals were to determine which geometric variables correlate with the energy performance, and to provide some guidelines to foster efficient LSF buildings in hot climates. By correlating six geometry-based indexes with the energy consumption for each construction element type group, it was verified that roofs do not show significant correlation, while exterior walls presented weak to moderate positive correlation with the building volume, very weak to weak negative correlation with the relative compactness, no correlation with the shape coefficient, moderate to strong negative correlation with the window-to-floor, window-to-wall, and window-to-exterior surface ratios. The results also show that buildings with larger windows and greater level of insulation have better energy performance. No significant difference of energy performance was found between different LSF construction systems with equivalent thermal resistance.
\end{abstract}

Keywords: generative design method, dynamic simulation, lightweight steel framed, residential buildings, hot arid climate

\section{Introduction}

Lightweight steel framed (LSF) buildings have a widespread use in the USA, Australia and

Japan and they are gaining market in Europe (Veljkovic \& Johansson, 2006). Indeed, the popularity

\footnotetext{
${ }^{*}$ Corresponding author.

Email address: eugenio.rodrigues@gmail.com (Eugénio Rodrigues)
} 
of LSF construction for use in residential buildings has been increasing in the recent years. This may be due to some advantages of LSF construction over heavyweight construction, pointed out by several authors (Gorgolewski, 2007; Martins et al., 2016; Santos et al., 2012, 2014; Soares et al., 2014, 2017c), such as: small weight with high mechanical strength; high architectural flexibility; rapid construction and reduced disruption onsite; great potential for recycling and reuse; high potential for retrofitting; easy prefabrication, allowing modular construction suited to the economy of mass production; economy in handling and transportation; superior quality, precise tolerances and high standards achieved by offsite manufacturing control.

Generally speaking, LSF is a dry construction system (Burstrand, 1998) consisting of three main sorts of materials that are used in walls and slabs: cold-formed steel studs for load bearing, sheathing panels (e.g., oriented strand boards and gypsum wallboards), and insulation materials (e.g., mineral wool and expanded polystyrene) (Höglund \& Burstrand, 1998). Waterproof and air tightness membranes are also used, as well as typical finishing layers. Further materials are needed for joining and fastening. For the ground floor, LSF buildings usually require a concrete slab, being the foundation work done with conventional methods (Veljkovic \& Johansson, 2006). The foundation size is typically smaller given the lightness feature of LSF construction. Soares et al. (2017c) provides an extended review on this kind of construction, pointing out the main features related with the energy efficiency and thermal performance of LSF construction.

Despite the advantages outlined above, the low thermal mass of LSF construction may be problematic for some functioning conditions and climates, leading to several comfort-related problems (e.g., overheating and larger temperature fluctuations). Kendrick et al. (2012) suggested that lightweight construction may lead to higher indoor temperatures during summer, particularly in the warmer future scenarios, due to the lack of thermal mass. Rodrigues et al. (2013d) also pointed out the problem of summer overheating in a low-energy steel framed house regarding warmer scenarios. Overheating may also lead to higher cooling energy demand. Sage-Lauck \& Sailor (2014) claimed that highly insulated and air-tight building envelopes tend to originate overheating during summer, which increases cooling energy demand or thermal discomfort in cases where no active cooling systems are installed. Phase change materials (PCMs) have been pointed out by several authors as a way to increase the thermal mass of lightweight construction (Sage-Lauck \& Sailor, 2014 Evola et al., 2013, Evola \& Marletta, 2014, Mandilaras et al., 2013, Rodriguez-Ubinas et al., 2013). However, as referred by Soares et al. (2013), these materials are more promising in climates with high thermal load variation during the day, to allow for melting and solidification processes of the PCM to occur (considering the phase change temperature in the range of indoor thermal comfort temperatures). In hot climates, like Kuwait, which is the case under study in this paper, the discharging of PCMs may be somehow problematic, due to continuously operating cooling 
systems, typically employed to guarantee indoor thermal comfort. Therefore, PCMs will be out of the scope of this paper. On the other hand, other construction features, which may be related to overheating will be investigated, such as geometry-based indicators and the level of envelope insulation.

As suggested by Kaynakli (2012), thermal insulation is known to play a critical role in energy saving by reducing the rate of heat transfer through the building envelope. In the literature, it is referred that the level of insulation should be increased in colder climates to reduce the energy demand for heating. On the other hand, the insulation level can be reduced in warmer climates and the ventilation and free cooling strategies should be improved to reduce the energy needs for cooling. Despite these general rules, no performance-driven guidelines or standards are found in the literature to support practitioners in the design of more energy efficient LSF dwellings in hot climates. This is probably due to the unpopularity of this sort of constructions in these climates, or because the technology has not reached those markets yet. Therefore, what would be the best level of insulation for such climate conditions? Which geometric variables would better correlate with the energy consumption of the building? And finally, can LSF construction be used to promote an energy and carbon-efficient built environment in hot climate countries? To answer these questions, an integrated energy performance-driven generative design methodology is proposed in this paper, as several features have to be considered simultaneously when a high-performance building design is attempted.

Generative design methods are typically used to assist building designers to produce new and alternative design solutions in an automated procedure (Kalay, 2004), thus helping them in their divergent thinking and design exploration (Singh \& Gu, 2012). These computer-based algorithms can produce large number of solutions and take over tedious tasks (Chakrabarti et al., 2011), which are otherwise costly and very time consuming. These algorithms have been applied to several aspects of building design, such as replication of architectural styles (Wonka et al., 2003), mass housing (Duarte, 2005), facade design (Caldas, 2008), furniture allocation in spaces (Merrell et al., 2011), etc.

With the rise of public concern about sustainability and energy efficiency, the design paradigm has drifted from the binomial form and function to the performance-based approach (Kalay, 1999, Oxman, 2008). To evaluate the building's design performance, several tools have been developed to assess energy consumption, visual comfort, construction cost, life-cycle cost, indoor air quality and thermal comfort, etc. One of those tools is the dynamic simulation of energy in buildings (DSEB). If the DSEB is coupled with generative design methods, it is possible to evaluate and compare the performance of a large number of alternative solutions (Rodrigues et al., 2015) or even to improve those solutions with optimization techniques (Evins, 2013; Machairas et al., 2014; Rodrigues et al. 
2014b; Wu et al., 2016; Jalal \& Bani, 2017).

As pointed out by Soares et al. (2017a), by producing a large set of building designs, with some sort of generative methods, and by evaluating their performance with DSEB tools, it is possible to carry out a statistical study of the influence of some particular parameter. This work presents such kind of approach by producing synthetic datasets of LSF residential buildings in hot climate conditions (in this case, in Kuwait), using a generative design method developed to create alternative building floor plans that have the same design program (Rodrigues et al., 2013b c a $)$ (i.e., the same rooms, spaces connectivity, openings, and other requirements and constraints). The buildings are then evaluated in a multi-zone fashion using the EnergyPlus software (version 8.7.0) to evaluate the influence of the climatic conditions, occupancy, lighting and equipment profiles, air-conditioning setpoints, and construction system on the energy demand for HVAC, in order to assess the energy consumption of each building. Finally, the dataset is statistically analyzed to determine which geometric variables correlate with the buildings' performance. The influence of the LSF construction system itself in the energy consumption of the building is also evaluated, mainly concerning the level of insulation, in order to provide some guidelines to foster efficient modular LSF residential buildings in hot climate conditions.

\section{Methodology}

This study follows a step-by-step methodology (Fig. 1): firstly, the climate region is chosen and the urban context is selected; secondly, the construction systems are defined and the geometric and topologic requirements and constraints are identified, considering the Kuwaiti cultural context and the local house design programs. Then, the building performance specifications are identified according to the 2010 building energy code of Kuwait (MEW, 2010). The next step is devoted to the generation of the synthetic dataset of buildings. It comprises three main parts: the production of random geometries using a generative design method; the DSEB study, and the evaluation of the energy demand of each generated geometry. Finally, the statistical analysis is carried out to correlate some geometry-based indexes and the energy consumption of each type of construction.

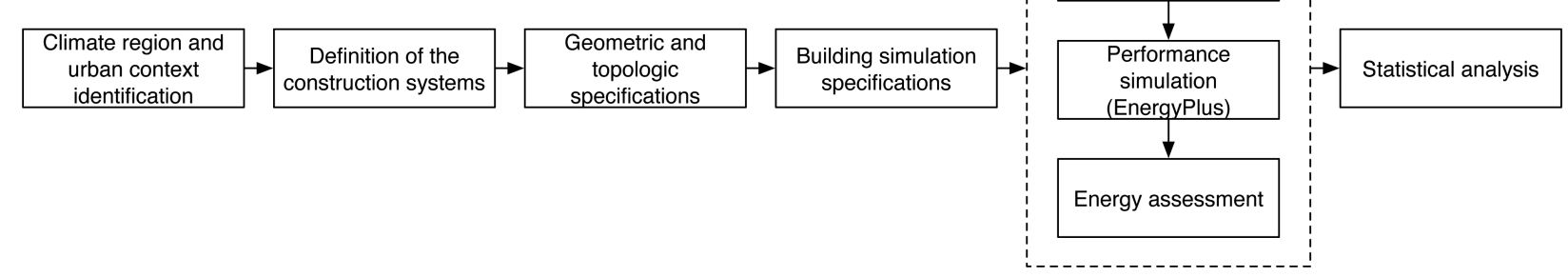

Fig. 1. Methodology steps. 


\subsection{Hot climates - the case study of Kuwait}

In this paper, the region of Kuwait is chosen to demonstrate how the proposed energy performancedriven generative design methodology can be used to foster modular LSF residential buildings in hot climates. The KISR Kuwait International Airport - KWT weather data file is used for the EnergyPlus runs. Moreover, the building construction activities in the country and the characteristic electricity demand in the residential sector are used as background context. It is believed that the assumptions made for the Kuwaiti reality can be somehow extrapolated and generalized to neighboring Gulf countries or even to the Middle East and North Africa (MENA) region countries with the similar weather conditions.

The expanding housing demand in Kuwait has forced new residential developments, alongside with large-scale city masterplan proposals. Indeed, Kuwait is one of the leading countries in the Middle East in terms of construction activity (AlSanad et al., 2011), and the assessment of the economic and environmental benefits of promoting energy efficiency in buildings is in the forefront of the government policies to promote a more sustainable development.

As pointed out by Krarti (2014), between 2002 and 2011 the annual electricity peak demand in Kuwait has increased from $\approx 7000 \mathrm{MW}$ to $\approx 11000 \mathrm{MW}$ and, at a rate of increase of about 6\%, the Ministry of Energy and Water expects the annual peak demand to be 15000 MW by 2020 and over 20000 MW by 2030, almost doubling the peak load in only 20 years. In fact, at $13000 \mathrm{kWh}$ per person, the annual energy consumption per capita in Kuwait is among the highest in the world (Alotaibi, 2011). The high level of energy demand can be partly attributed to the harsh summer climate with the consequent demand for cooling, but also to inefficient construction practices and installed equipment, as well as energy-intensive lifestyle choices (Al-Mumin et al. 2003). Indeed, buildings account for almost $70 \%$ of the total primary energy consumption in Kuwait (Ameer \& Krarti, 2016), and air conditioning accounts for $70 \%$ of the electricity annual peak load and $45 \%$ of the yearly electricity consumption (MEW, 2010). In addition, as suggested by Ameer \& Krarti (2016), the high energy consumption can be attributed to significant energy subsidies. In order to reduce building energy use in Kuwait, the 2010 energy conservation program of the Ministry of Electricity and Water (MEW, 2010) establishes several requirements to improve the energy performance of buildings (including insulation, glazing, lighting and ventilation requirements) and to reduce power ratings of air-conditioning systems.

Based on a TRNSYS-IISIBAT environment DSEB parametric study, Al-ajmi \& Hanby (2008) proposed several features that should be adopted in hot climate conditions to achieve more energy efficient residential buildings, such as: the control of the window area and the "north-south di- 
rection" placement of the main windowed facades, the use of treated glazing to reduce solar heat gains, and the reduction of the amount of uncontrolled air infiltration rates. Al-Mumin et al. (2003) evaluated the influence of the occupants' behavior and activity patterns on the energy consumption of the Kuwaiti dwellings. Krarti (2015) has assessed the implementation of an energy efficiency retrofit program in existing Kuwaiti buildings to meet the 2010 energy conservation program expressed in terms of savings in energy use and peak demand. Several energy efficiency measures were evaluated related to the glazing type, windows size, temperature settings, and coefficient of performance of the air conditioning system. Soares et al. $(2017 \mathrm{~b})$ carried out an EnergyPlus based DSEB parametric study to explore the advantages of using PCM-wallboards in dwellings in Kuwait. The authors have evaluated the impact of PCM-wallboards on the reduction of both cooling demand and peak-loads, and they have concluded that a $4 \mathrm{~cm}$ thick PCM-wallboard with a melting-peak temperature of $24{ }^{\circ} \mathrm{C}$ yielded the lowest annual cooling demand (annual cooling energy savings of 4-5\%) across a variety of room orientation and window-to-wall ratio $(W W R)$, assuming a cooling-setpoint of $24{ }^{\circ} \mathrm{C}$. Moreover, they concluded that cooling demand and peak-loads can be reduced by 5-7\% during summer months.

In all the references listed above, only heavyweight constructions were evaluated in the studies, and no information about the behavior of lightweight residential buildings in hot arid climate conditions was found in the literature. Therefore, to complement the previous works, this manuscript explores the thermal performance of LSF low-rise air-conditioned residential buildings in Kuwait. As far as the authors know, this paper is the first study devoted to such analysis.

\subsection{Construction system}

In this paper, the "LSF System B(A)" will be used. It is available on the market (urb, 2017) and it was developed by Balthazar Aroso Arquitectos Lda. (bal, 2017). The main particularity of this LSF system is that a single cold-formed shape profile (C100 x $45 \times 1.2 \mathrm{~mm})$ is used for all the steel framing elements, which makes the construction more rational.

Regarding thermal behavior, LSF construction elements are typically classified according to the location of the thermal insulation layers as cold-framed, hybrid, and warm-framed construction (Fig. 2). In cold-framed construction, the thermal insulation is placed inside the wall between the steel studs; in hybrid construction, the thermal insulation is distributed between the external surface and the wall gap between steel studs; and finally, in warm-framed construction, all thermal insulation is placed outside the steel framing on the external surface.

In order to evaluate the thermal performance of these different LSF construction systems in hot arid conditions, and to assess the best level of insulation, several exterior wall design solutions are considered in the DSEB runs. This is done by varying the thicknesses of both the thermal 


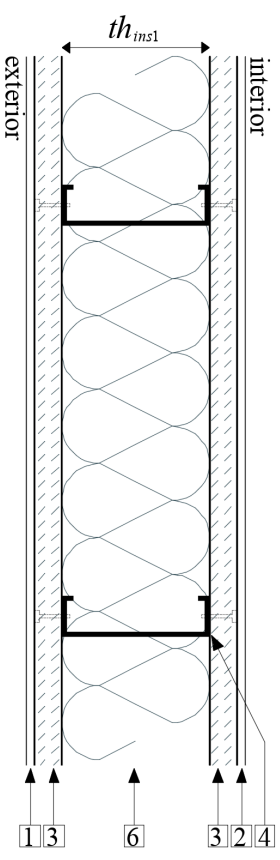

(a)

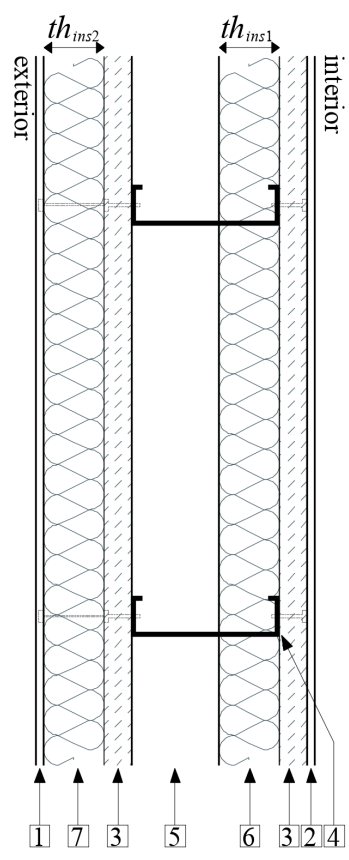

(b)

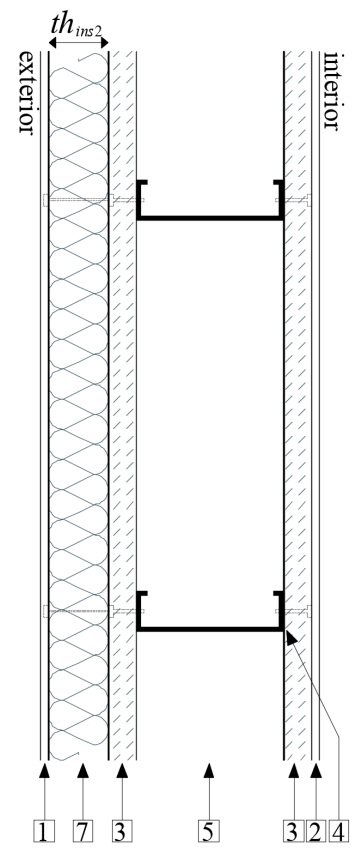

(c)
11 Exteior finishing layer

2 Interior finishing layer

3 OSB

4 Steel frames

5 Air gap

6 Thermal insulation crossing the steel frames

7 Thermal insulation by the exterior

Fig. 2. Classification of LSF construction elements depending on the position of the thermal insulation layers: a) cold-framed construction, b) hybrid construction and c) warm-framed construction.

insulation within the steel framing, $t h_{i n s 1}$, and the thermal insulation placed from the exterior, $t h_{\text {ins } 2}$ (Fig. 2). $t h_{i n s 1}$ can be assigned one of the 11 predefined values $t h_{i n s 1}=\{0,1,2, \cdots, 10\} \mathrm{cm}$ and $t h_{\text {ins } 2}$ can be equal to any of $\{0,1,2, \cdots, 5\} \mathrm{cm}$. Regarding the roof system, the thickness of the XPS layer can vary within the range $t h_{\text {ins } 3}=\{0,1,2, \cdots, 10\} \mathrm{cm}$ (Fig. 2). Therefore, a set of 66 predefined discrete exterior walls (11 cold-framed, 5 warm-framed and 50 hybrid walls) and 11 roof solutions can be considered in the simulations, which means that 726 combinations of different exterior walls and roofs are possible. Fig. 3 shows a sketch of the main components of an LSF building. Fig. 4 also shows the cross-section of some construction elements considered in the model. Table 1 lists the thermophysical properties of the materials considered in this study.

The non-homogenous layers and the effect of thermal bridges (originated by the steel framing) are considered in the DSEB according to the methodology described in Soares et al. (2014). Following this methodology, a fictitious equivalent material is defined to replace the heterogeneous layers; for instance, the space between steel frames filled with insulation. As a result, the thermal conductivity of the equivalent material is adjusted so that the effective thermal resistance of the equivalent layer is equal to that of the heterogeneous layer. The density and the specific heat of the equivalent material are also adjusted to match the thermal capacity of the heterogeneous layer as proposed by Soares et al. (2014).

In addition, $U$-values are obtained by varying the thickness of the thermal insulation layers as explained above. The simplified method proposed by Gorgolewski (2007) and Doran \& Gorgolewski 


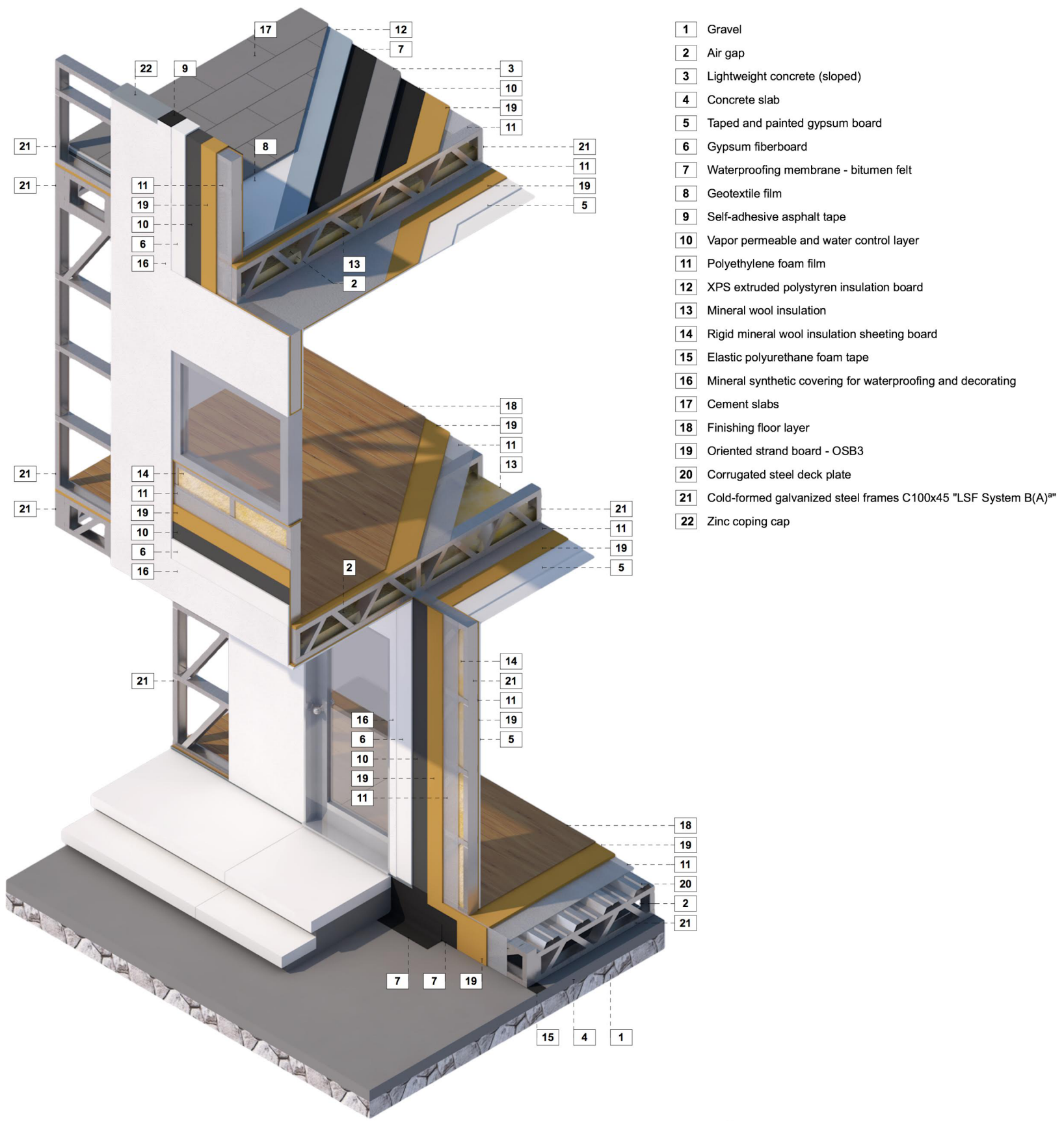

Fig. 3. Schematic view of the main components of a LSF System B(A) (not to scale).

(2002) to calculate the $U$-values of LSF walls is used in this paper. The method is similar to the one referred in ISO 6946:2007 (2007) for warm-framed construction, but it was improved for cold-framed and hybrid walls as explained by Gorgolewski (2007). Generally speaking, the method involves the calculation of the upper and lower limits of the thermal resistance of the LSF elements, $R_{\max }$ and $R_{\min }$ respectively. The conductances associated to $R_{\max }$ and $R_{\min }$ are then calculated on an area-weighted basis. For the walls, the stud and nogging spacing is equal to $625 \mathrm{~mm}$. The flange width is $45 \mathrm{~mm}$. The studs are $100 \mathrm{~mm}$ deep and they are made of $1.2 \mathrm{~mm}$ thick steel. For the roofs and floors, the beam spacing is also equal to $625 \mathrm{~mm}$. Moreover, for the purposes 


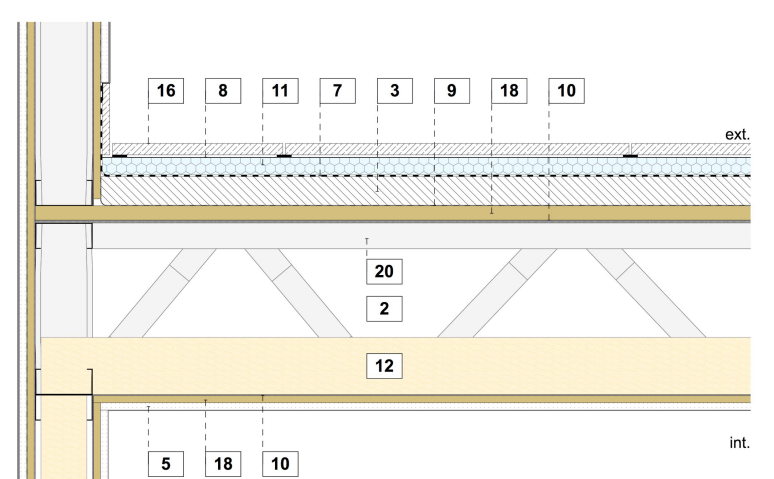

(a)

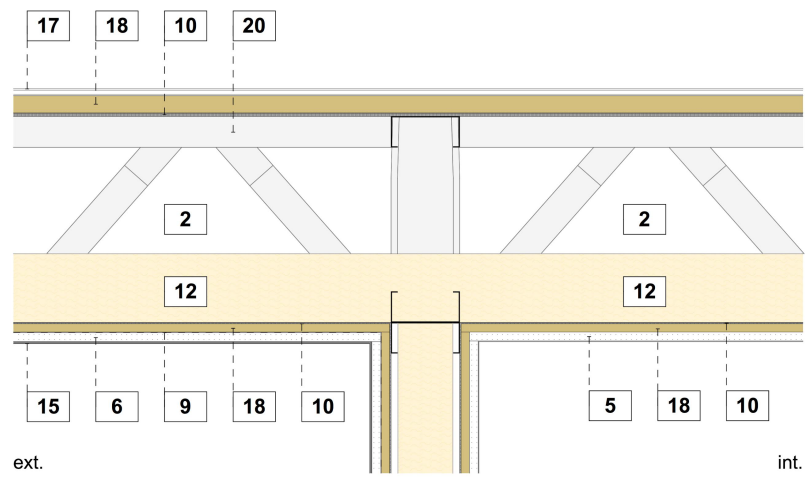

(c)

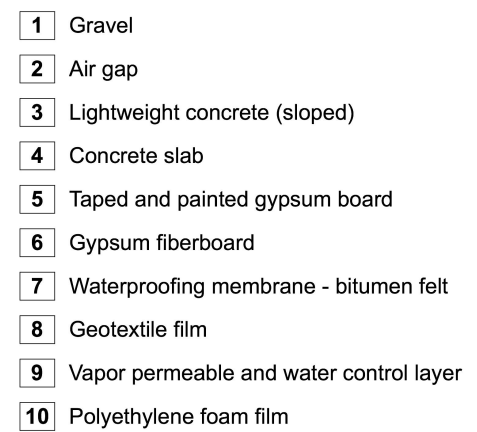

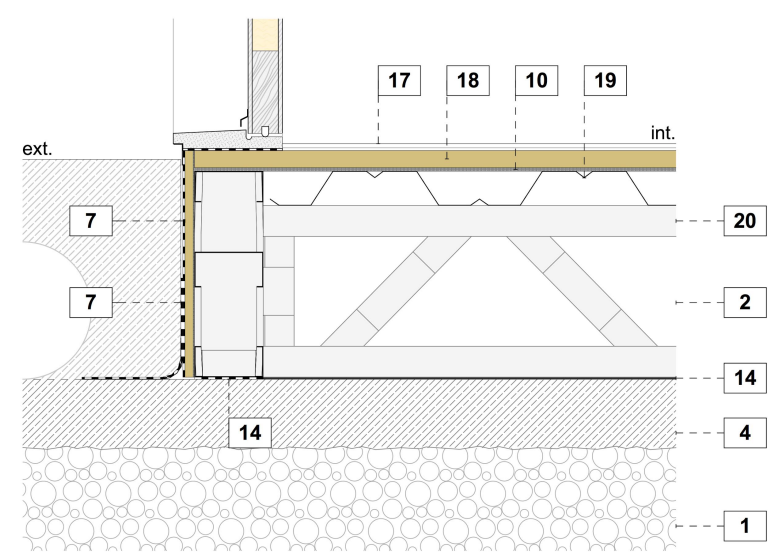

(b)

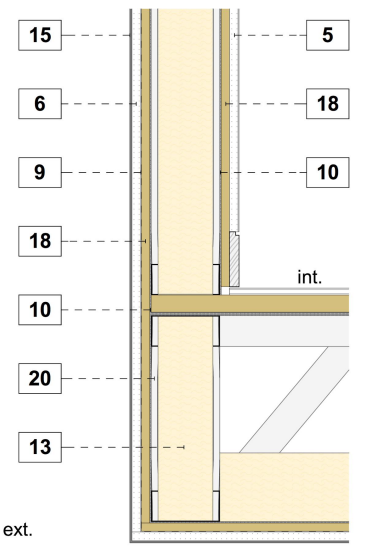

(d)

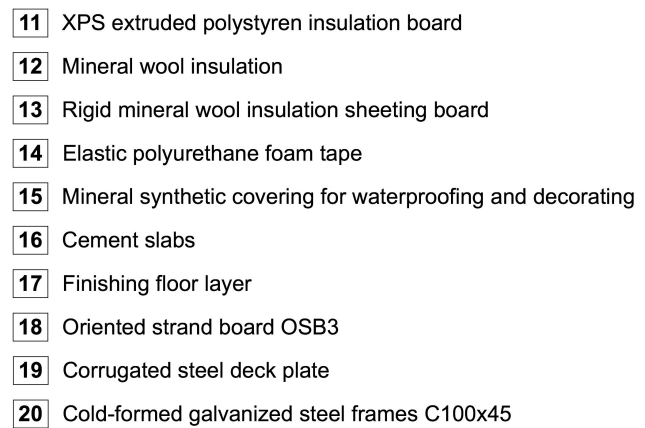

Fig. 4. Cross-section of some LSF System B(A) ${ }^{a}$ construction elements considered in the model: a) accessible flat roof, b) ground floor, c) exterior floor/interior ceiling and d) cold-framed exterior wall (not to scale).

of this study, the fraction of the area taken up by the webs of the steel studs, noggings and braces adds up to $0.72 \%$ and $0.83 \%$ for the walls and roof/floors, respectively. The internal surface resistance $\left(R_{s i}\right)$ is considered equal to $0.13 \mathrm{~m}^{2} \cdot \mathrm{K} \cdot \mathrm{W}^{-1}$ (horizontal heat flux), $0.10 \mathrm{~m}^{2} \cdot \mathrm{K} \cdot \mathrm{W}^{-1}$ (heat flow upwards) or $0.17 \mathrm{~m}^{2} \cdot \mathrm{K} \cdot \mathrm{W}^{-1}$ (heat flow downwards). The external surface resistance $\left(R_{s e}\right)$ is equal to $0.04 \mathrm{~m}^{2} \cdot \mathrm{K} \cdot \mathrm{W}^{-1}$. Finally, the $U$-value is given by Eq. (1), where the total thermal resistance $\left(R_{T}\right)$ is obtained by Eq. (2).

$$
U=\left(1 / R_{T}\right)+\Delta U_{g}+\Delta U_{f}
$$


Table 1. Thermophysical properties of the building components.

\begin{tabular}{|c|c|c|c|c|}
\hline Material & $\begin{array}{c}k \\
\left(\mathrm{~W} \cdot \mathrm{m}^{-1} \cdot \mathrm{K}^{-1}\right) \\
\end{array}$ & $\begin{array}{c}c_{p} \\
\left(\mathrm{~J} \cdot \mathrm{kg}^{-1} \cdot \mathrm{K}^{-1}\right) \\
\end{array}$ & $\begin{array}{c}\rho \\
\left(\mathrm{kg} \cdot \mathrm{m}^{-3}\right) \\
\end{array}$ & $\begin{array}{c}R \\
\left(\mathrm{~m}^{2} \cdot \mathrm{K} \cdot \mathrm{W}^{-1}\right) \\
\end{array}$ \\
\hline Gravel & 1 & 900 & 1700 & \\
\hline Lightweight concrete (sloped) & 0.53 & 840 & 1280 & \\
\hline Concrete slab & 1.27 & 900 & 2100 & \\
\hline Gypsum board & 0.25 & 1000 & 900 & \\
\hline Gypsum fiberboard & 0.32 & 1100 & 1100 & \\
\hline Waterproofing membrane - bitumen felt & 0.23 & 1800 & 1050 & \\
\hline Polyethylene foam film & 0.05 & 2400 & 30 & \\
\hline XPS & 0.034 & 1400 & 35 & \\
\hline EPS - ETICS & 0.04 & 1400 & 15 & \\
\hline Mineral wool insulation & 0.038 & 800 & 30 & \\
\hline Rigid mineral wool insulation sheeting board & 0.04 & 840 & 100 & \\
\hline Mineral synthetic covering for waterproofing and decoration & 0.72 & 1000 & 1860 & \\
\hline EIFS finish & 0.7 & 1000 & 1700 & \\
\hline Cement slabs & 1.3 & 900 & 2100 & \\
\hline Finishing floor layer & 0.17 & 1400 & 1200 & \\
\hline OSB & 0.13 & 1700 & 650 & \\
\hline Steel & 50 & 500 & 7833 & \\
\hline \multicolumn{5}{|l|}{ Air cavity } \\
\hline $0.01 \mathrm{~m}$ - Horizontal heat flux & & & & 0.15 \\
\hline $0.02 \mathrm{~m}$ - Horizontal heat flux & & & & 0.17 \\
\hline$\geq 0.03 \mathrm{~m}$ - Horizontal heat flux & & & & 0.18 \\
\hline $0.2 \mathrm{~m}-$ Heat flow upwards & & & & 0.16 \\
\hline $0.2 \mathrm{~m}$ - Heat flow downwards & & & & 0.23 \\
\hline
\end{tabular}

$$
R_{T}=p R_{\max }+(1-p) R_{\text {min }}
$$

The value of $p$ is equal to 0.5 for warm-framed construction. In cold-framed and hybrid construction, a $p$ of 0.5 may not be appropriated since the thermal resistance throughout the area close to the steel can be considerably lower than that in the area away from the metal element. As explained by Doran \& Gorgolewski (2002), the value of $p$ is influenced by several factors, including the flange width, the spacing between studs and the depth of the stud. The method described by Doran \& Gorgolewski (2002) and Gorgolewski (2007) will be used to determine the $U$-value of exterior cold-framed and hybrid walls; the method described in ISO 6946:2007 will be used to determine the $U$-value of warm-framed walls, exterior roofs and floors $(p=0.5)$.

Doran \& Gorgolewski (2002) explain the method used in this paper in more detail, providing the main equations to determine the $U$-value of different LSF elements, including some corrections to account for air gaps in insulating layers $\left(\Delta U_{g}\right)$ and metal fixings penetrating insulating layers $\left(\Delta U_{f}\right)$. The authors also provide some examples to illustrate the calculation of the $U$-value of each type of LSF construction. For the purposes of this study, the corrections $\Delta U_{g}$ and $\Delta U_{f}$ are ignored, assuming that they together amount to less than $3 \%$ of $1 / R_{T}$, as prescribed by Doran \& Gorgolewski (2002). Table 2 summarizes (as an example) the $U$-value of some LSF elements. 
Table 2. $U$-value of some LSF construction elements (materials listed along the cross-section area away from the steel element).

\begin{tabular}{|c|c|c|c|c|}
\hline & Material & $\begin{array}{l}\text { Thickness } \\
(\mathrm{m})\end{array}$ & $\begin{array}{c}R_{T} \\
\left(\mathrm{~m}^{2} \cdot \mathrm{K} \cdot \mathrm{W}^{-1}\right) \\
\end{array}$ & $\begin{array}{c}U \\
\left(\mathrm{~W} \cdot \mathrm{m}^{-2} \cdot \mathrm{K}^{-1}\right)\end{array}$ \\
\hline Exterior wall & EIFS finish & 0.003 & \multirow{8}{*}{3.023} & \multirow{8}{*}{0.331} \\
\hline Hybrid construction & EPS - ETICS & 0.05 & & \\
\hline$t h_{\text {ins } 1}=0.1 \mathrm{~m}$ & OSB & 0.012 & & \\
\hline \multirow[t]{5}{*}{$t h_{\text {ins } 2}=0.05 \mathrm{~m}$} & Polyethylene foam film & 0.002 & & \\
\hline & Rigid mineral wool sheeting board & 0.1 & & \\
\hline & Polyethylene foam film & 0.002 & & \\
\hline & OSB & 0.012 & & \\
\hline & Gypsum board & 0.013 & & \\
\hline \multirow{9}{*}{$\begin{array}{l}\text { Exterior wall } \\
\text { Hybrid construction } \\
t h_{i n s 1}=0.06 \mathrm{~m} \\
t h_{i n s 2}=0.05 \mathrm{~m}\end{array}$} & EIFS finish & 0.003 & \multirow{9}{*}{2.845} & \multirow{9}{*}{0.351} \\
\hline & EPS - ETICS & 0.05 & & \\
\hline & OSB & 0.012 & & \\
\hline & Polyethylene foam film & 0.002 & & \\
\hline & Air gap & 0.04 & & \\
\hline & Rigid mineral wool sheeting board & 0.06 & & \\
\hline & Polyethylene foam film & 0.002 & & \\
\hline & OSB & 0.012 & & \\
\hline & Gypsum board & 0.013 & & \\
\hline \multirow{8}{*}{$\begin{array}{l}\text { Exterior wall } \\
\text { warm-framed construction } \\
t h_{\text {ins } 1}=0.00 \mathrm{~m} \\
t h_{\text {ins } 2}=0.05 \mathrm{~m}\end{array}$} & EIFS finish & 0.003 & \multirow{8}{*}{1.885} & \multirow{8}{*}{0.53} \\
\hline & EPS - ETICS & 0.05 & & \\
\hline & OSB & 0.012 & & \\
\hline & Polyethylene foam film & 0.002 & & \\
\hline & Air gap & 0.1 & & \\
\hline & Polyethylene foam film & 0.002 & & \\
\hline & OSB & 0.012 & & \\
\hline & Gypsum board & 0.013 & & \\
\hline \multirow{9}{*}{$\begin{array}{l}\text { Exterior wall } \\
\text { cold-framed construction } \\
t h_{\text {ins } 1}=0.10 \mathrm{~m} \\
t h_{\text {ins } 2}=0.00 \mathrm{~m}\end{array}$} & Mineral synthetic covering & 0.003 & \multirow{9}{*}{1.429} & \multirow{9}{*}{0.7} \\
\hline & Gypsum fiberboard & 0.013 & & \\
\hline & OSB & 0.012 & & \\
\hline & Polyethylene foam film & 0.002 & & \\
\hline & Air gap & 0.04 & & \\
\hline & Rigid mineral wool insulation board & 0.06 & & \\
\hline & Polyethylene foam film & 0.002 & & \\
\hline & OSB & 0.012 & & \\
\hline & Gypsum board & 0.013 & & \\
\hline \multirow{7}{*}{$\begin{array}{l}\text { Partition wall } \\
\text { cold-framed construction }\end{array}$} & Gypsum board & 0.013 & \multirow{7}{*}{1.569} & \multirow{7}{*}{0.637} \\
\hline & OSB & 0.012 & & \\
\hline & Polyethylene foam film & 0.002 & & \\
\hline & Rigid mineral wool insulation board & 0.1 & & \\
\hline & Polyethylene foam film & 0.002 & & \\
\hline & OSB & 0.012 & & \\
\hline & Gypsum board & 0.013 & & \\
\hline Roof & Cement slabs & 0.02 & & \\
\hline \multirow[t]{10}{*}{$t h_{\text {ins } 3}=0.10 \mathrm{~m}$} & XPS & 0.1 & & \\
\hline & Waterproofing membrane - bitumen felt & 0.003 & & \\
\hline & Lightweight concrete (sloped) & 0.05 & & \\
\hline & OSB & 0.025 & & \\
\hline & Polyethylene foam film & 0.002 & 5.347 & 0.187 \\
\hline & Air gap & 0.2 & & \\
\hline & Mineral wool insulation & 0.1 & & \\
\hline & Polyethylene foam film & 0.002 & & \\
\hline & OSB & 0.012 & & \\
\hline & Gypsum board & 0.013 & & \\
\hline Exterior floor & Mineral synthetic covering & 0.003 & & \\
\hline & Gypsum fiberboard & 0.013 & & \\
\hline & OSB & 0.012 & & \\
\hline & Polyethylene foam film & 0.002 & & \\
\hline & Mineral wool insulation & 0.1 & 2.423 & 0.413 \\
\hline & Air gap & 0.2 & & \\
\hline & Polyethylene foam film & 0.002 & & \\
\hline & OSB & 0.025 & & \\
\hline & Finishing floor layer & 0.01 & & \\
\hline
\end{tabular}




\subsection{Design program specification}

The urban and social policies in Kuwait have created a strong state reliance concerning housing rights and property as with Kuwaiti nationality come many advantages, such as the provision of housing welfare to all Kuwaiti families. The policy of the Public Authority for Housing Welfare (PAHW) is based on a single-family detached housing model - the Kuwaiti villa. Indeed, as stated by Alshalfan (2013), only 1088 units out of the 93040 housing units provided by the government between 1954 and 2012 were apartments. This villa-based social housing program has been challenging the urban process of neighborhoods and the city itself. In one hand, it requires more land-use masterplans, resulting in more infrastructure requirements; it treats all Kuwaiti families' needs equally, and it conceptualizes the city as a flat landscape (Alshalfan, 2013). This state dependent housing process may also create little room for innovation in the construction sector. On the other hand, the simplification of the housing provision system has created an attractive case study scenario for developing urban building energy modelling (UBEM) tools to evaluate districtwide energy demand and supply strategies, as residential buildings are grouped into a very specific "archetype" (to characterize simulation inputs for UBEM), which is the villa model itself (Cerezo et al., 2017).

The LSF system described in section 2.2 is applied to a typical government sponsored residential villa. Typically, a Kuwaiti villa is a 3-story house, which occupies a plot of land measuring at least $400 \mathrm{~m}^{2}$ (Alshalfan, 2013). Regarding the functioning architectural program, an archetypal villa is composed by corridors/halls and sleeping, living and entertainment spaces, and it has a separate area for domestic staff accommodation distributed over three stories ( $L_{1}$ to $\left.L_{3}\right)$ with aimed story height of $3.0 \mathrm{~m}$. Generally speaking, the ground floor contains three bathrooms, two bedrooms, one kitchen and two living rooms; the first floor comprises four bedrooms, three bathrooms, and one resting room; the second floor contains one bathroom, one bedroom, and one laundry room. The specified spaces/rooms requirements are summarized in Table 3. For each space, there are exterior openings, which are listed and detailed in Table 4. These rooms were grouped into clusters according to Table 5. The interior openings and rooms relations are presented in Table 6. The listed functioning architectural program will be used in the generative design study.

To evaluate the energy performance of the villa model in an urban context, the Al-Qadisiyah residential area in Kuwait City was selected as case study, as shown in Fig. 5. As stated by Cerezo et al. (2015), Al-Qadisiyah is a neighborhood representative of most residential areas in the city, and it is composed by two to three stories villas organized in eight blocks of 200 houses each, plus a central block for public services. Fig. 5 also shows a schematic view of the villa urban context to be used in this study, which is composed by the villa to be evaluated itself and the front, back and side neighboring villas. In the simulations, the surrounding buildings are considered to act as 
Table 3. Rooms geometry and topologic specifications.

\begin{tabular}{|c|c|c|c|c|c|c|c|c|}
\hline Room & $C^{s n}$ & $C^{s f}$ & $C^{r i}$ & $C^{s l}$ & $C^{s u}$ & $C^{s s}(\mathrm{~m})$ & $C^{s s r}$ & $C^{s l r}$ \\
\hline$S_{1}$ & Stair & Circulation & - & $L_{1}$ & $L_{3}$ & - & - & - \\
\hline$S_{2}$ & Hall & Circulation & Min & $L_{1}$ & $L_{1}$ & 2.00 & $\{2.0,3.0\}$ & $\{5.0,1.5\}$ \\
\hline$S_{3}$ & Corridor & Circulation & Min & $L_{1}$ & $L_{1}$ & 1.10 & $\{2.0,3.0\}$ & $\{5.0,1.5\}$ \\
\hline$S_{4}$ & Living room & Living & High & $L_{1}$ & $L_{1}$ & 3.40 & 1.7 & 2.0 \\
\hline$S_{5}$ & Couple bedroom & Living & Mid & $L_{1}$ & $L_{1}$ & 3.20 & 1.7 & 2.0 \\
\hline$S_{6}$ & Bathroom & Service & Min & $L_{1}$ & $L_{1}$ & 1.40 & 1.7 & 2.0 \\
\hline$S_{7}$ & Corridor & Circulation & Min & $L_{1}$ & $L_{1}$ & 1.10 & $\{2.0,3.0\}$ & $\{5.0,1.5\}$ \\
\hline$S_{8}$ & Public bathroom & Service & Min & $L_{1}$ & $L_{1}$ & 1.40 & 1.7 & 2.0 \\
\hline$S_{9}$ & Business room & Living & Max & $L_{1}$ & $L_{1}$ & 3.60 & 1.7 & 2.0 \\
\hline$S_{10}$ & Kitchen & Service & High & $L_{1}$ & $L_{1}$ & 2.80 & 1.7 & 2.0 \\
\hline$S_{11}$ & Service entrance & Circulation & Min & $L_{1}$ & $L_{1}$ & 1.20 & $\{2.0,3.0\}$ & $\{5.0,1.5\}$ \\
\hline$S_{12}$ & Storage room & Utility & Min & $L_{1}$ & $L_{1}$ & 1.40 & 1.7 & 2.0 \\
\hline$S_{13}$ & Servant entrance & Circulation & Min & $L_{1}$ & $L_{1}$ & 1.20 & $\{2.0,3.0\}$ & $\{5.0,1.5\}$ \\
\hline$S_{14}$ & Servant bedroom & Living & Min & $L_{1}$ & $L_{1}$ & 2.00 & 1.7 & 2.0 \\
\hline$S_{15}$ & Servant bathroom & Service & Min & $L_{1}$ & $L_{1}$ & 1.40 & 1.7 & 2.0 \\
\hline$S_{16}$ & Resting room & Living & Mid & $L_{2}$ & $L_{2}$ & 2.80 & 1.7 & 2.0 \\
\hline$S_{17}$ & Storage room & Utility & Min & $L_{2}$ & $L_{2}$ & 1.40 & 1.7 & 2.0 \\
\hline$S_{18}$ & Corridor & Circulation & Min & $L_{2}$ & $L_{2}$ & 1.10 & $\{2.0,3.0\}$ & $\{5.0,1.5\}$ \\
\hline$S_{19}$ & Couple bedroom & Living & Mid & $L_{2}$ & $L_{2}$ & 3.20 & 1.7 & 2.0 \\
\hline$S_{20}$ & Bathroom & Service & Min & $L_{2}$ & $L_{2}$ & 1.40 & 1.7 & 2.0 \\
\hline$S_{21}$ & Couple bedroom & Living & Mid & $L_{2}$ & $L_{2}$ & 3.20 & 1.7 & 2.0 \\
\hline$S_{22}$ & Bathroom & Service & Min & $L_{2}$ & $L_{2}$ & 1.40 & 1.7 & 2.0 \\
\hline$S_{23}$ & Corridor & Circulation & Min & $L_{2}$ & $L_{2}$ & 1.10 & $\{2.0,3.0\}$ & $\{5.0,1.5\}$ \\
\hline$S_{24}$ & Couples bedroom & Living & High & $L_{2}$ & $L_{2}$ & 3.60 & 1.7 & 2.0 \\
\hline$S_{25}$ & Couple bedroom & Living & Mid & $L_{2}$ & $L_{2}$ & 3.20 & 1.7 & 2.0 \\
\hline$S_{26}$ & Bathroom & Service & Min & $L_{2}$ & $L_{2}$ & 1.40 & 1.7 & 2.0 \\
\hline$S_{27}$ & Corridor & Circulation & Min & $L_{3}$ & $L_{3}$ & 1.10 & $\{2.0,3.0\}$ & $\{5.0,1.5\}$ \\
\hline$S_{28}$ & Servant bathroom & Service & Min & $L_{3}$ & $L_{3}$ & 1.40 & 1.7 & 2.0 \\
\hline$S_{29}$ & Laundry room & Service & Min & $L_{3}$ & $L_{3}$ & 1.40 & 1.7 & 2.0 \\
\hline$S_{30}$ & Servant bedroom & Living & Mid & $L_{3}$ & $L_{3}$ & 1.90 & 1.7 & 2.0 \\
\hline
\end{tabular}

shading objects, thus influencing the energy performance of the building under investigation. This is also an attempt to provide results that can be used in UBEM studies. Moreover, the existence of adjacent buildings is also important for the functioning architectural program of the villa model, as it may influence, for instance, the orientation of the building, the location of windows, etc.

\subsection{Dynamic simulation specification}

Regarding envelope construction parameters, the principles specified in section 2.2 are used for the opaque elements of the villa model. For the windows, the glazing type is a $6 \mathrm{~mm}$ doublereflective, with a solar heat gain coefficient of 0.25 and an $U$-value of $3.33 \mathrm{~W} \cdot \mathrm{m}^{-2} \cdot \mathrm{K}^{-1}$.

The envelope of the building shall be made to prevent air infiltration. Positive pressure must be maintained inside the building by the air-handling system to minimize air and dust infiltration. For that reason, a minimum ventilation rate of 0.25 air changes per hour $(\mathrm{ACH})$ for pressurization is considered in the model - the ventilation rate should be the highest of the three following rules:

- $0.25 \mathrm{ACH}$ for pressurization plus exhaust air from kitchens, toilet rooms and other areas;

- recommended air quantity per person as per latest ASHRAE ventilation standard; and,

- recommended air quantity per floor area as per latest ASHRAE ventilation standard. 
Table 4. Exterior openings geometry and topologic specifications.

\begin{tabular}{|c|c|c|c|c|c|c|}
\hline$C^{o s}$ & Opening & $C^{\text {oet }}$ & $C^{o e o}$ & $C^{\text {oew }}(\mathrm{m})$ & $C^{\text {oeh }}(\mathrm{m})$ & $C^{o e v}(\mathrm{~m})$ \\
\hline$S_{1}$ & - & - & - & - & - & - \\
\hline$S_{2}$ & $O e_{1}$ & Door & East & 1.40 & 2.00 & 0 \\
\hline$S_{3}$ & - & - & - & - & - & - \\
\hline$S_{4}$ & $O e_{2}, O e_{3}$ & $\{$ Window, Window $\}$ & - & $\{2.00,2.00\}$ & $\{1.00,1.00\}$ & $\{1.00,1.00\}$ \\
\hline$S_{5}$ & $\mathrm{Oe}_{4}$ & Window & - & 2.00 & 1.00 & 1.00 \\
\hline$S_{6}$ & $\mathrm{Oe}_{5}$ & Window & - & 1.00 & 1.00 & 1.00 \\
\hline$S_{7}$ & - & - & - & - & - & - \\
\hline$S_{8}$ & - & - & - & - & - & - \\
\hline$S_{9}$ & $O e_{6}, O e_{7}$ & $\{$ Door, Window $\}$ & $\{$ East,-$\}$ & $\{1.00,2.00\}$ & $\{2.00,1.00\}$ & $\{0,1.00\}$ \\
\hline$S_{10}$ & $O e_{8}, O e_{9}$ & $\{$ Door, Window $\}$ & - & $\{1.00,2.50\}$ & $\{2.00,1.00\}$ & $\{0,1.00\}$ \\
\hline$S_{11}$ & $O e_{10}$ & Door & - & 1.00 & 2.00 & 0 \\
\hline$S_{12}$ & - & - & - & - & - & - \\
\hline$S_{13}$ & $O e_{11}$ & Door & - & 1.00 & 2.00 & 0 \\
\hline$S_{14}$ & $O e_{12}$ & Window & - & 0.50 & 0.50 & 1.50 \\
\hline$S_{15}$ & - & - & - & - & - & - \\
\hline$S_{16}$ & $O e_{13}$ & Window & - & 2.00 & 1.00 & 1.00 \\
\hline$S_{17}$ & - & - & - & - & - & - \\
\hline$S_{18}$ & - & - & - & - & - & - \\
\hline$S_{19}$ & $O e_{14}$ & Window & - & 2.00 & 1.00 & 1.00 \\
\hline$S_{20}$ & $O e_{15}$ & Window & - & 1.00 & 1.00 & 1.00 \\
\hline$S_{21}$ & $O e_{16}$ & Window & - & 2.00 & 1.00 & 1.00 \\
\hline$S_{22}$ & $O e_{17}$ & Window & - & 1.00 & 1.00 & 1.00 \\
\hline$S_{23}$ & - & - & - & - & - & - \\
\hline$S_{24}$ & $O e_{18}$ & Window & - & 2.00 & 1.00 & 1.00 \\
\hline$S_{25}$ & $O e_{19}$ & Window & - & 2.00 & 1.00 & 1.00 \\
\hline$S_{26}$ & $O e_{20}$ & Window & - & 1.00 & 1.00 & 1.00 \\
\hline$S_{27}$ & $O e_{21}$ & Window & - & 1.00 & 2.00 & 0 \\
\hline$S_{28}$ & $O e_{22}$ & Window & - & 1.00 & 1.00 & 1.00 \\
\hline$S_{29}$ & $O e_{23}$ & Window & - & 0.80 & 1.00 & 1.00 \\
\hline$S_{30}$ & $O e_{24}$ & Window & - & 0.50 & 0.50 & 1.50 \\
\hline
\end{tabular}

Table 5. Clusters of rooms.

\begin{tabular}{ll}
\hline & \multicolumn{1}{c}{ Clusters } \\
\hline$G_{1}$ & $\left\{S_{3}, S_{4}, S_{5}, S_{6}\right\}$ \\
$G_{2}$ & $\left\{S_{7}, S_{8}, S_{9}\right\}$ \\
$G_{3}$ & $\left\{S_{10}, S_{11}, S_{12}\right\}$ \\
$G_{4}$ & $\left\{S_{13}, S_{14}, S_{15}\right\}$ \\
$G_{5}$ & $\left\{S_{18}, S_{19}, S_{20}, S_{21}, S_{22}\right\}$ \\
$G_{6}$ & $\left\{S_{23}, S_{24}, S_{25}, S_{26}\right\}$ \\
$G_{7}$ & $\left\{S_{27}, S_{28}, S_{29}, S_{30}\right\}$ \\
\hline
\end{tabular}

Accordingly, the ventilation rates considered in the model for the different building zones are presented in Table 7. The intake airflow rates are considered constant to ensure continuous pressurization, while the exhaust flow rate profiles are based on the occupation (bathrooms) and cooking equipment operation (kitchen) schedules defined, which are based on the profiles presented by AlMumin et al. 2003 - Fig. 6. The constant pressurization is also guaranteed by an equivalent intake airflow rate into the building, whenever exhaust ventilation takes place.

Regarding the outdoor air infiltration into the building, it is not considered for the majority of the building zones, as there is continuous pressurization. However, in the zones with high usage external access doors (hall and kitchen), even while pressurized, infiltration is considered to take place due to the doors opening, which is assumed to occur during the main occupation/movement periods: from $6 \mathrm{~h} 00$ until $23 \mathrm{~h} 00$ in the hall, and from $5 \mathrm{~h} 00$ until $23 \mathrm{~h} 00$ in the kitchen. For that 
Table 6. Interior openings geometry and topologic specifications.

\begin{tabular}{ccccccc}
\hline & \multicolumn{5}{c}{ Interior Openings } \\
Opening & $C^{\text {oit }}$ & $C^{\text {oia }}$ & $C^{\text {oib }}$ & $C^{\text {oiw }}(\mathrm{m})$ & $C^{\text {oih }}(\mathrm{m})$ & $C^{\text {oiv }}(\mathrm{m})$ \\
\hline$O i_{1}$ & Door & $S_{2}$ & $S_{1}$ & 1.00 & 2.00 & 0 \\
$O i_{2}$ & Door & $S_{16}$ & $S_{1}$ & 1.00 & 2.00 & 0 \\
$O i_{3}$ & Door & $S_{27}$ & $S_{1}$ & 1.00 & 2.00 & 0 \\
\hline$O i_{4}$ & Door & $S_{2}$ & $S_{3}$ & 1.40 & 2.00 & 0 \\
$O i_{5}$ & Door & $S_{3}$ & $S_{4}$ & 1.00 & 2.00 & 0 \\
$O i_{6}$ & Door & $S_{3}$ & $S_{5}$ & 1.00 & 2.00 & 0 \\
$O i_{7}$ & Door & $S_{3}$ & $S_{6}$ & 0.80 & 2.00 & 0 \\
$O i_{8}$ & Door & $S_{2}$ & $S_{7}$ & 0.90 & 2.00 & 0 \\
$O i_{9}$ & Door & $S_{7}$ & $S_{8}$ & 0.90 & 2.00 & 0 \\
$O i_{10}$ & Door & $S_{7}$ & $S_{9}$ & 0.80 & 2.00 & 0 \\
$O i_{11}$ & Door & $S_{2}$ & $S_{10}$ & 1.00 & 2.00 & 0 \\
$O i_{12}$ & Door & $S_{11}$ & $S_{10}$ & 1.00 & 2.00 & 0 \\
$O i_{13}$ & Door & $S_{11}$ & $S_{12}$ & 1.00 & 2.00 & 0 \\
$O i_{14}$ & Door & $S_{13}$ & $S_{14}$ & 1.00 & 2.00 & 0 \\
$O i_{15}$ & Door & $S_{13}$ & $S_{15}$ & 0.80 & 2.00 & 0 \\
\hline$O i_{16}$ & Door & $S_{16}$ & $S_{17}$ & 1.00 & 2.00 & 0 \\
$O i_{17}$ & Door & $S_{16}$ & $S_{18}$ & 1.00 & 2.00 & 0 \\
$O i_{18}$ & Door & $S_{18}$ & $S_{19}$ & 1.00 & 2.00 & 0 \\
$O i_{19}$ & Door & $S_{18}$ & $S_{20}$ & 1.00 & 2.00 & 0 \\
$O i_{20}$ & Door & $S_{18}$ & $S_{21}$ & 0.80 & 2.00 & 0 \\
$O i_{21}$ & Door & $S_{18}$ & $S_{22}$ & 0.80 & 2.00 & 0 \\
$O i_{22}$ & Door & $S_{16}$ & $S_{23}$ & 1.00 & 2.00 & 0 \\
$O i_{23}$ & Door & $S_{23}$ & $S_{24}$ & 1.00 & 2.00 & 0 \\
$O i_{24}$ & Door & $S_{23}$ & $S_{25}$ & 1.00 & 2.00 & 0 \\
$O i_{25}$ & Door & $S_{23}$ & $S_{26}$ & 0.80 & 2.00 & 0 \\
\hline$O i_{26}$ & Door & $S_{27}$ & $S_{28}$ & 0.80 & 2.00 & 0 \\
$O i_{27}$ & Door & $S_{27}$ & $S_{29}$ & 1.00 & 2.00 & 0 \\
$O i_{28}$ & Door & $S_{27}$ & $S_{30}$ & 1.00 & 2.00 & 0 \\
\hline$C^{o i t}-$ type, & \\
\hline oiw & - opening's space, $_{-}$minimum & width,,$C^{\text {oih }}-$ minimum height, Coiv & vertical position \\
\hline
\end{tabular}

Table 7. Intake and exhaust ventilation maximum rates considered in the model (based on ASHRAE 2013a).

\begin{tabular}{ll|rccc}
\hline & & \multicolumn{4}{|c}{ Ventilation rate (max. value) } \\
Zone type & Ventilation type & $\mathrm{ACH}$ & $\mathrm{L} \cdot \mathrm{s}^{-1} \cdot \mathrm{person}^{-1}$ & $\mathrm{~L} \cdot \mathrm{s}^{-1} \cdot \mathrm{m}^{-2}$ & $\mathrm{~L} \cdot \mathrm{s}^{-1}$ \\
\hline Living and circulation & Intake & 0.25 & 2.5 & 3 & \\
Laundry & Intake & 0.25 & 2.5 & 6 & \\
Kitchen & Exhaust & & & & $50^{a}$ \\
Bathroom & Exhaust & & & & $25^{a}$ \\
\hline$a-$ intermittent & & \multicolumn{4}{l}{}
\end{tabular}

matter, half of the air leakage maximum legal limit for swinging doors is assumed $\left(1.3 \mathrm{~L} \cdot \mathrm{s}^{-1} \cdot \mathrm{m}^{-2}\right)$, as the doors are not permanently opened and these zones are also pressurized.

The characterization of the occupancy patterns, the operation schedules of appliances, lighting, and air-conditioning thermostat settings are done deterministically based on available literature (Al-Mumin et al., 2003). Regarding occupancy, 12 people are considered to inhabit the building (10 family members and 2 servants), distributed in the different zones according to the occupancy patterns depicted in Fig. 7. Residual occupancy patterns are also considered in the circulation zones (stairs, hall, corridors, etc.) and in the laundry. The maximum assumed number of people per zone and the respective activity level, which accounts for the internal heat gains due to occupancy, are presented in Table 8 .

The requirements from the Kuwaiti energy conservation code (MEW, 2010) are also considered 


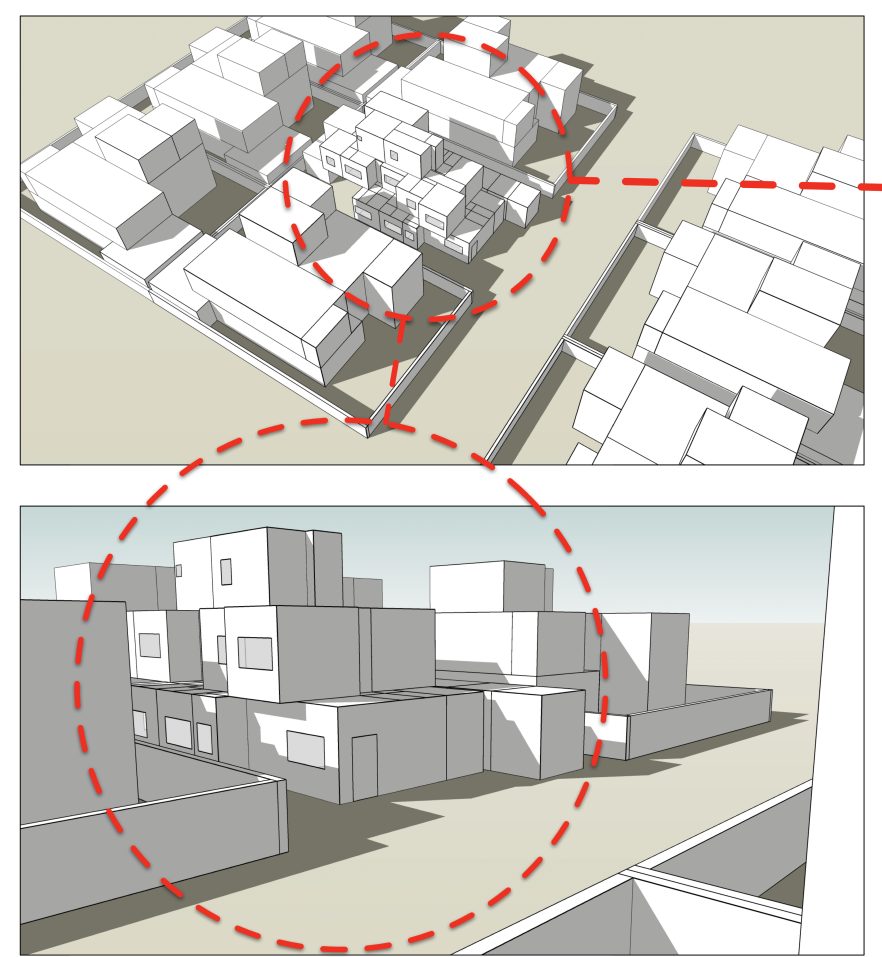

(b)

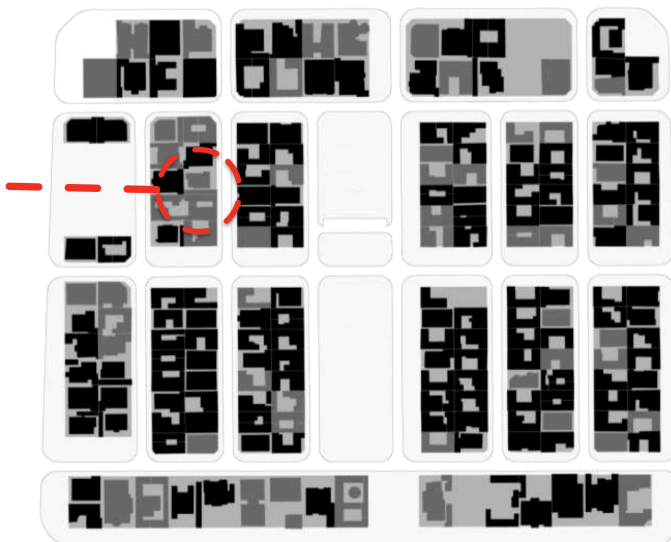

(a)

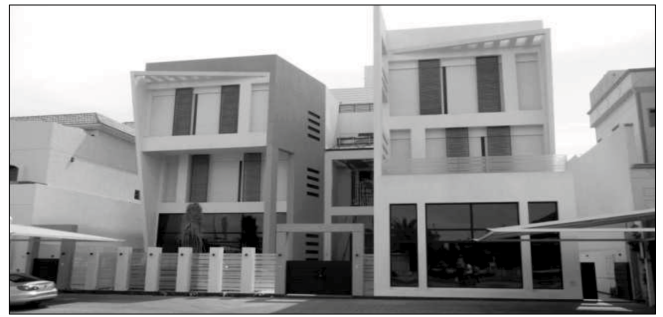

(c)

Fig. 5. (a) Al-Qadisiyah neighborhood in Kuwait City - Block 8 - used as reference neighborhood (figure adapted from Cerezo et al. 2015). (b) Schematic view of the villa model composed by the house to be evaluated itself and the neighborhood villas. (c) Photographic view of a new modern villa in Kuwait City (figure adapted from Cerezo et al. 2015).

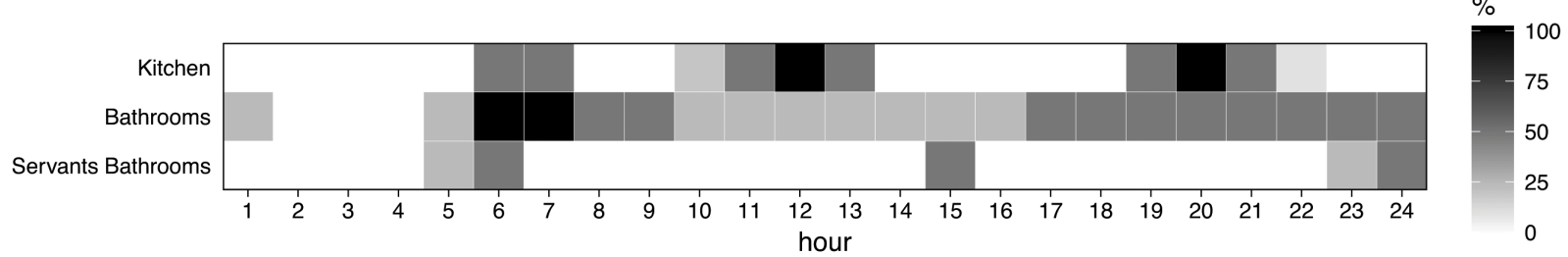

Fig. 6. Exhaust ventilation schedules.

Table 8. Maximum number of people per zone and correspondent activity levels.

\begin{tabular}{|c|c|c|}
\hline Zone type & Max. number of people ${ }^{a}$ & Activity level $\left(\mathrm{W} \cdot\right.$ person $\left.^{-1}\right)$ \\
\hline Living rooms & 5 & 110 \\
\hline Single bedrooms & 1 & 72 \\
\hline Couple bedrooms & $2^{b}$ & 72 \\
\hline Couples bedroom & 4 & 72 \\
\hline Kitchen & 12 & 190 \\
\hline Bathrooms & 2 & 207 \\
\hline Servants' bathrooms & 1 & 207 \\
\hline Corridor \& entrances & $1-3$ & 190 \\
\hline Hall & 10 & 190 \\
\hline Stair & 12 & 190 \\
\hline Laundry room & 1 & 250 \\
\hline
\end{tabular}




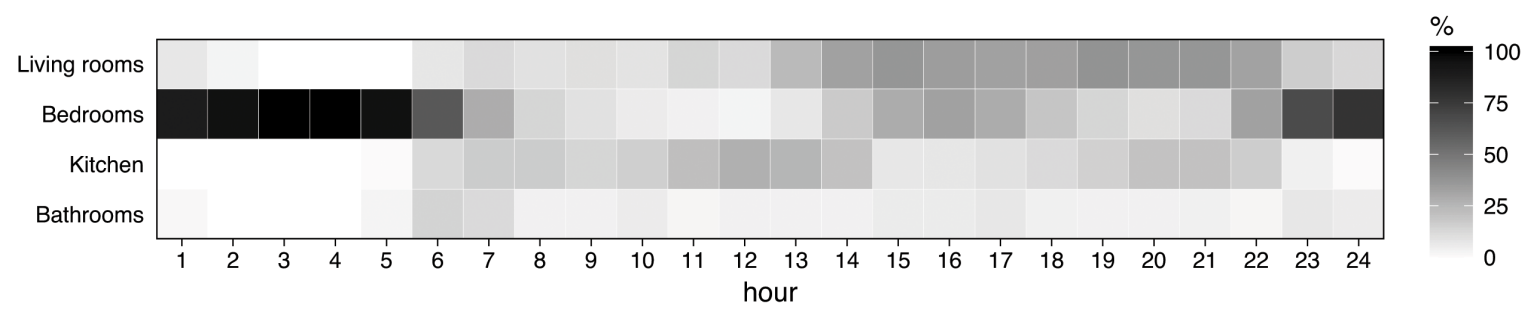

Fig. 7. General occupancy patterns in the main building zone types (based on Al-Mumin et al. 2003).

in the model for lighting - i.e., a maximum design lighting level of $7 \mathrm{~W} \cdot \mathrm{m}^{-2}$. The lighting schedules are based on the patterns presented in (Al-Mumin et al., 2003) and on the building zones typology, occupancy, and window shading, and are depicted in Fig. 8 for the different zones. For the living rooms, bedrooms, and kitchen, two types of schedules are defined - low outdoor temperature (Fig. 8a) and high outdoor temperature (Fig. 8b) -, as more lighting is required during high outdoor temperature periods, due to continuous window shading. For this purpose, the low outdoor temperature period was defined between 1 December and 28 February, when the maximum daily air temperature is below $30^{\circ} \mathrm{C}$, and the high outdoor temperature period for the remaining 9 months $(1$ March - 30 November; Kuwait air temperatures obtained from Soares et al. 2017b). Accordingly, for all windowed zones, the window shadings (exterior PVC roller shutters) are considered to permanently cover the windows during the high outdoor temperature period, and to only cover them at night-time during the low outdoor temperature period. For the remaining zones, single yearly schedules are considered (Fig. 8c), independently of the dual window shading profile, as their lighting profiles can be considered constant throughout the year, due to these zones typology and occupancy.

The internal heat gains due to electric equipment are defined by the maximum design wattage levels of the appliances typically found in each zone, which are based on the building zones typology (ASHRAE 2013b; Park 2013; NNP 2014; DoE 2016b; Table 9). The corresponding usage schedules are based on the patterns presented in (Al-Mumin et al. 2003) and on the building zones typology and occupancy, and are depicted in Fig. 9 for the different zones. Schedules for bathrooms and servant bedrooms are not presented since they correspond to short usage periods. Additionally, a $2230 \mathrm{~W}$ gas oven is also considered to contribute to the kitchen's internal heat gains (radiant fraction of 0.07 , convection fraction of 0.93 ). The oven usage schedule corresponds to the kitchen's exhaust ventilation schedule (see Fig. 6).

The villa is air-conditioned considering an ideal loads air system model in the EnergyPlus runs, which allows to assess the performance of the building without modelling a full HVAC system, meeting all the load requirements and consuming no energy (DoE, 2016a). The air temperature thermostat is set with a cooling setpoint temperature of $23.9{ }^{\circ} \mathrm{C}$ and a heating setpoint of $21.1{ }^{\circ} \mathrm{C}$ 


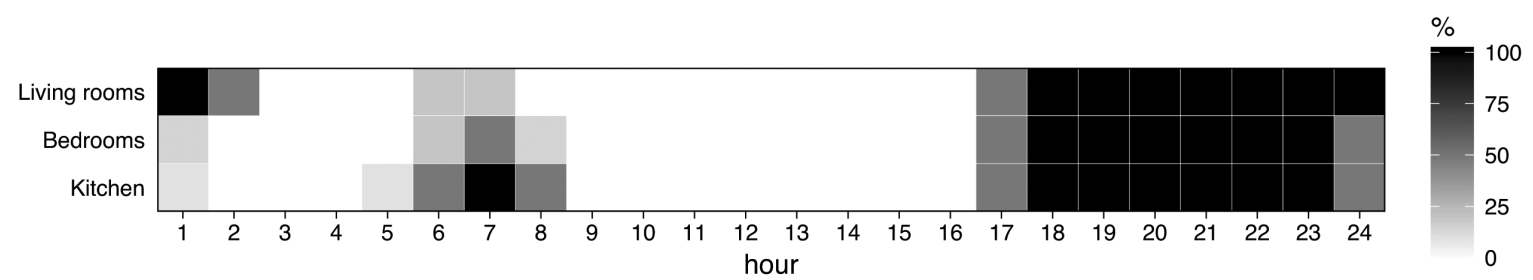

(a) Low outdoor temperature lighting schedules.

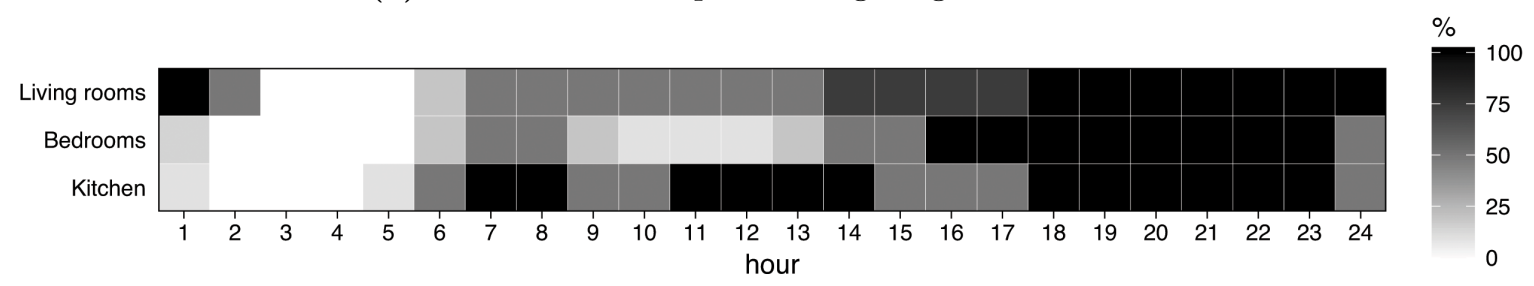

(b) High outdoor temperature lighting schedules.

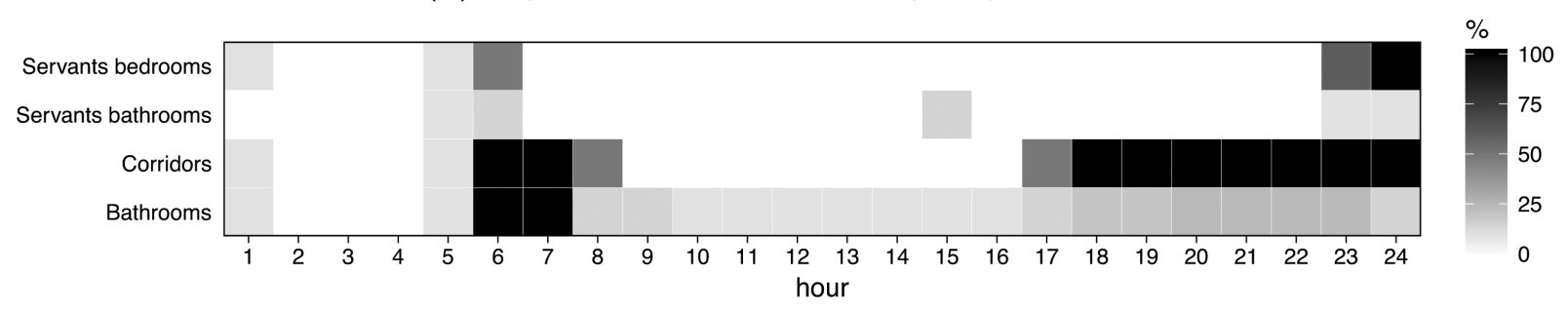

(c) Yearly lighting schedules.

Fig. 8. Electric light schedule in each zone type.

Table 9. Total heat gains from electric equipment in each zone.

\begin{tabular}{lcccc}
\hline Zone type & Design level $(\mathrm{W})$ & Radiant fraction & Latent fraction & Convection fraction \\
\hline Living rooms & 1144 & 0.34 & 0 & 0.66 \\
Bedrooms & 1003 & 0.33 & 0 & 0.67 \\
Servants' bedrooms & 127 & 0.4 & 0 & 0.6 \\
Kitchen & 6538 & 0.34 & 0.05 & 0.61 \\
Bathrooms ${ }^{a}$ & 1073 & 0.35 & 0 & 0.65 \\
Laundry room & 1518 & 0.32 & 0.1 & 0.58 \\
\hline${ }^{a}$ - Except public bathroom (no equipment considered).
\end{tabular}

in the cooler months. A 50\% dehumidification setpoint is also considered during the cooling season. The heating season - when heating is available - was defined for the period between 1 November and 31 March, when the average daily temperature is permanently, or, at least, for long periods of time, below the heating setpoint. On the other hand, the cooling season - when cooling is available - was defined for the period between 1 March and 30 November, when the average daily temperature is permanently, or, at least, for long periods, above the cooling setpoint (Kuwait air temperatures obtained from Soares et al. 2017b). The air-conditioning availability schedules for each zone are depicted in Fig. 10, and were defined according to the zones typology and occupancy. The only nonclimatized zones are the bathrooms, storage rooms, and servant and cooking entrances. However, the bathrooms are indirectly climatized by dragging conditioned air from the adjacent zones during exhaustion (see Fig. 6). Moreover, due to the high electric equipment heat gains in the kitchen and laundry, there is only cooling available in these zones. 


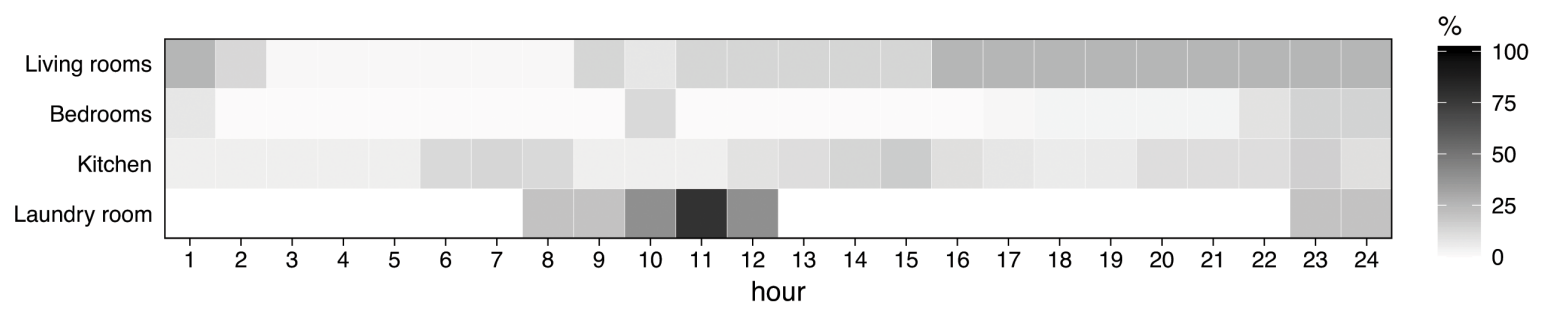

Fig. 9. Electric equipment schedules in each zone type.

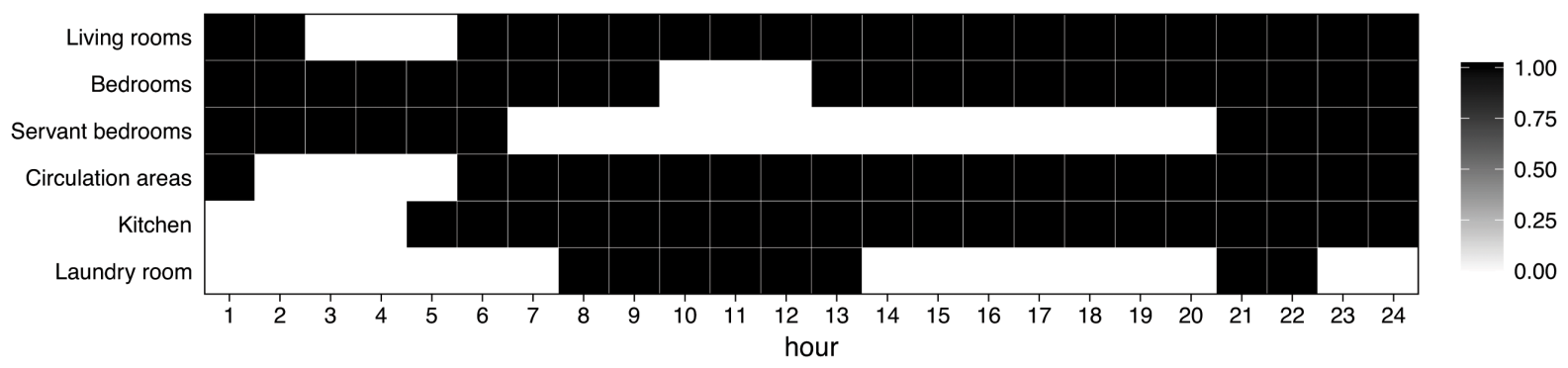

Fig. 10. Air-conditioning availability schedules for living rooms, bedrooms, servant bedrooms, hall and circulation areas, kitchen (cooling only), and laundry (cooling only).

\subsection{Generative design method}

The buildings will be created using the new version of the Evolutionary Program for the Space Allocation Problem (EPSAP) (Rodrigues et al., 2013b c a). The EPSAP algorithm generates alternative floor plans according to the user preferences and requirements. The algorithm is a two-stage hybrid approach having in the first stage an Evolution Strategy (ES) where the usual mutation operator is substituted by a Stochastic Hill Climbing (SHC) technique, which performs a set of geometric transformations, such as translation, rotation, stretch, mirror, etc. These transformations are applied to single objects (openings and spaces), clusters of objects, stories, or the whole building. The new algorithm version is extended to 17 penalty functions in weighted sum cost function to be minimized. The new penalty functions are: layout gross and construction area, story gross area, circulation space area, space fixed position, space relative importance, opening accessibility, and opening fixed position functions. From these new functions, only the space relative importance (compares spaces dimensions and penalizes if a space with lower importance is bigger than other with higher importance), the circulation space area (penalizes horizontal and vertical spaces excess floor area), and the opening accessibility (evaluates if there are sufficient clear areas before and after an opening to be a safe passage) were used in this study. After the buildings were generated, these are evaluated using the coupled dynamic simulation software (EnergyPlus) according to the selected performance objective criteria (Rodrigues et al., 2014a). 


\subsection{Synthetic dataset}

The synthetic dataset was created using three computers to generate 6010 buildings, with random constructions for roofs (11 types) and exterior walls (66 types), totalizing 726 combinations. The buildings' geometry, performance, and construction elements properties (opaque and transparent elements) were saved in the end of each run. The building geometry data includes the number of spaces, windows, doors, stories, etc., surface areas for walls, roofs, floors, openings, and building volume. In the cases of exterior walls and openings, the surface areas are also split into cardinal orientations (North, South, East, and West). The building performance data includes energy consumption, water consumption, thermal discomfort, and active systems and building electric consumption. The building construction data presents the main thermophysical properties of opaque and transparent elements. This dataset is publicly available (Rodrigues et al., 2018).

\section{Results and Discussion}

The generated buildings varied in their geometry. Fig. 11 presents eight examples of the 6010 buildings in the dataset. The building shape, volume, and openings orientation vary randomly from design to design. However, the openings keep the same size in every generated building (e.g., the room $S_{5}$ has a window with $2.0 \mathrm{~m}$ width and $1.0 \mathrm{~m}$ height in all 6010 buildings).

Relatively to the construction elements, the 11 roof types and the 66 exterior wall types produced 726 construction combinations that varied randomly throughout (the set of) 6010 geometries. Fig. 12 presents the histogram of the frequency of buildings per construction combination. As it can be seen in the histogram, the frequency per construction combination of random element types varies between 1 and 20 buildings, thus covering all possible combinations. When the 6010 buildings are divided into subgroups according to the roof (ER) or exterior wall (EW) types, the number of buildings for roof types varies between 475 and 576 and the number of buildings for exterior wall types between 68 and 115 .

Fig. 13 depicts a) the range of performance (in terms of building energy consumption $E$ for air-conditioning) by construction element subgroup (min, max, and mean average), with color mapping indicating roof elements (grey), hybrid walls (white), warm-framed walls (yellow), and cold-framed walls (blue); b) the thermal transmittance of each construction element; c) the coefficient of determination $\left(\mathrm{R}^{2}\right)$ of the energy consumption $E$ correlations with the geometry-based indexes; and, d) the calculated probability of the null hypothesis $\left(\mathrm{H}_{0}\right.$ is confirmed when $p$-value is above or equal to 0.01) for the subgroup sample against the geometry-based indexes $(V$ - volume, $C_{f}$ - shape coefficient, $R C$ - relative compactness, $W F R$ - window-to-floor ratio, $W W R$ window-to-wall ratio, and $W S R$ - window-to-exterior surface ratio). 

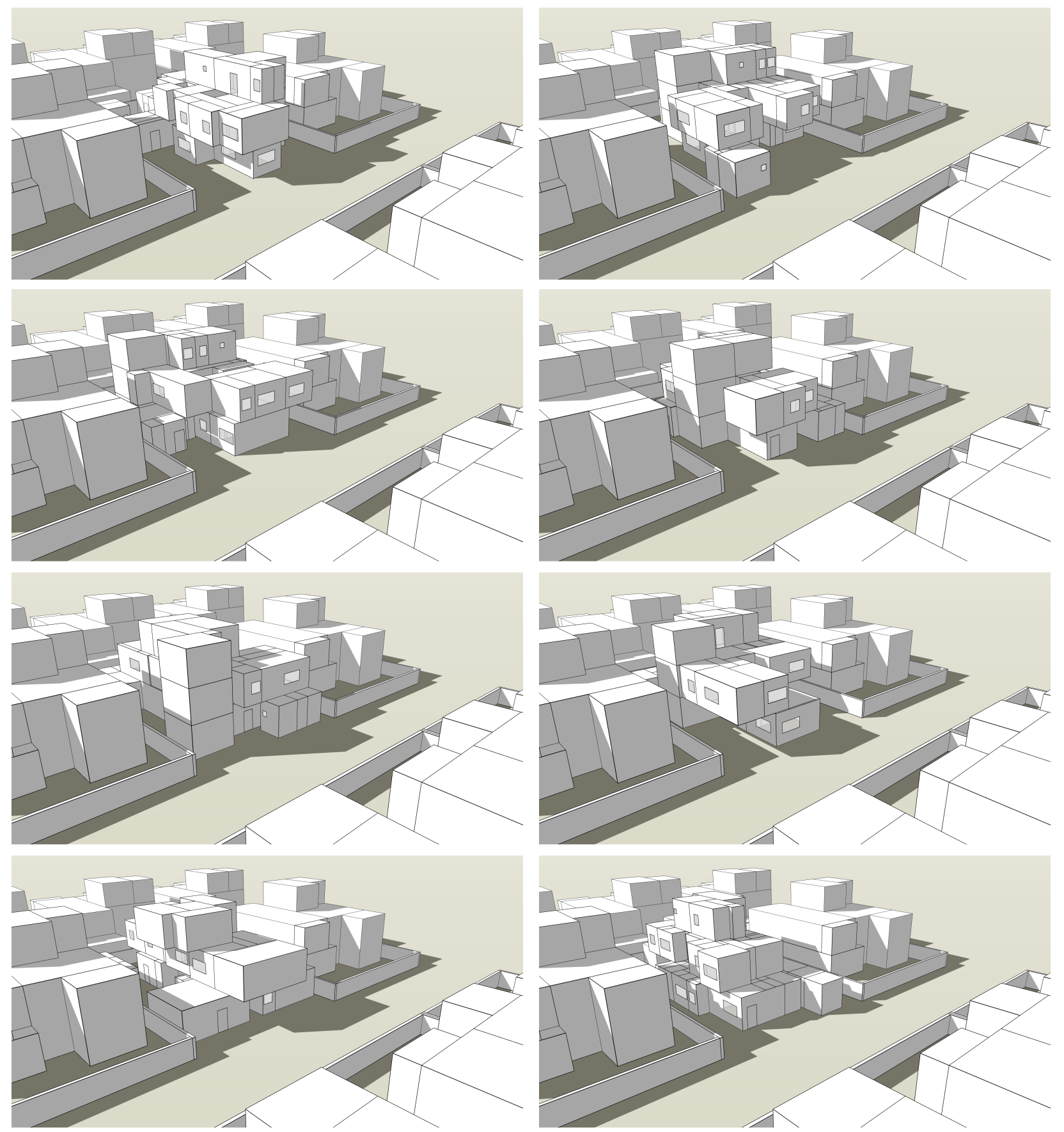

Fig. 11. Example of eight buildings generated by the new version of the EPSAP algorithm of the Kuwaiti building program in the urban context.

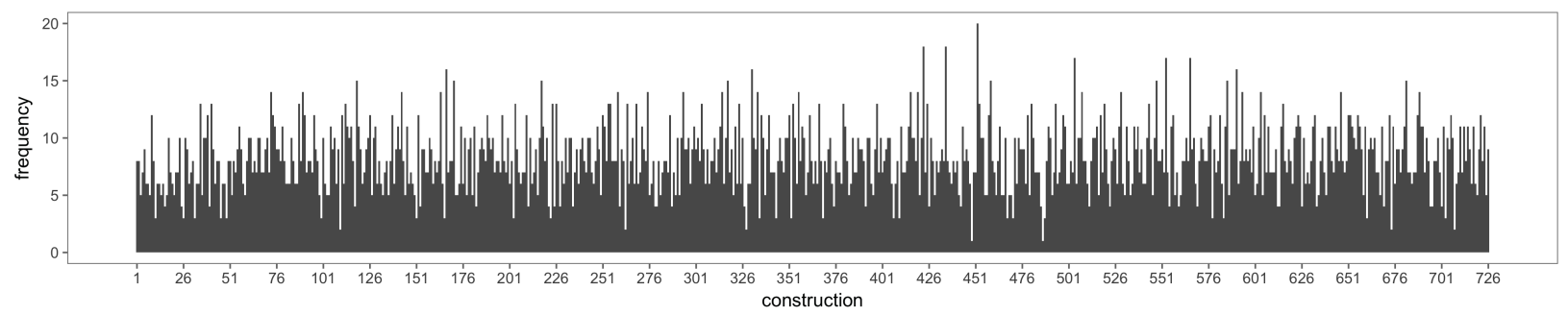

Fig. 12. Histogram of construction elements combination. There are 11 roof types and 66 exterior wall types (totalizing 726 combinations). 


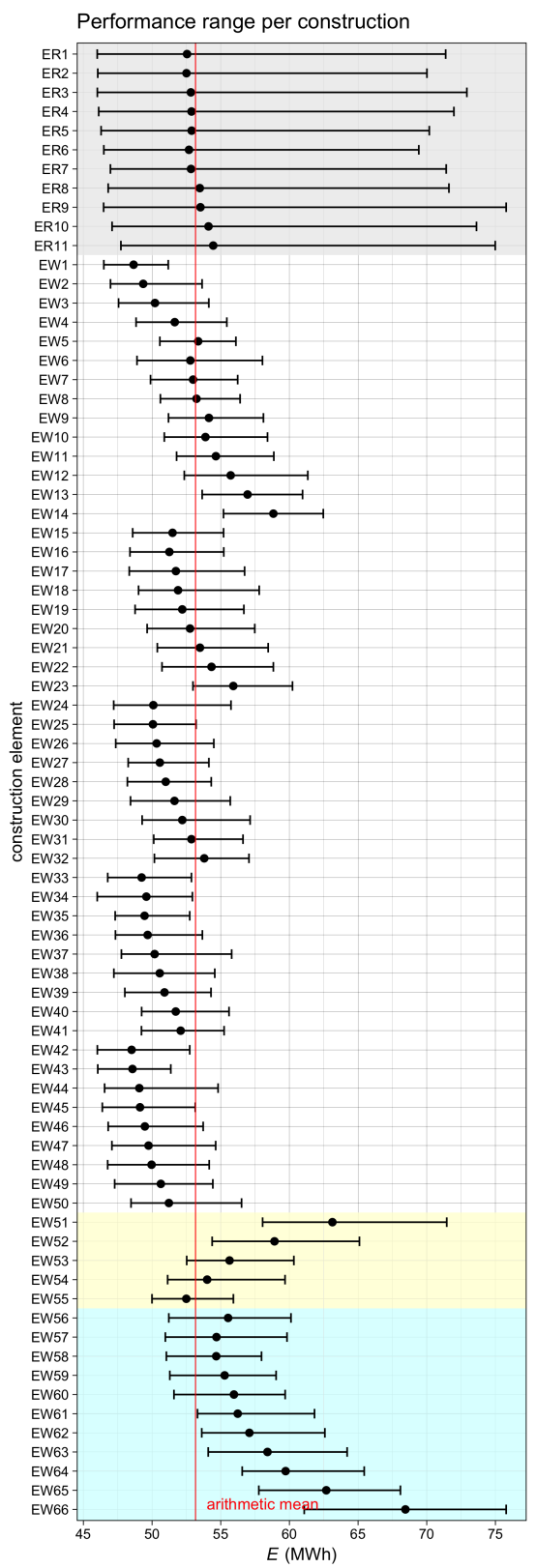

(a)

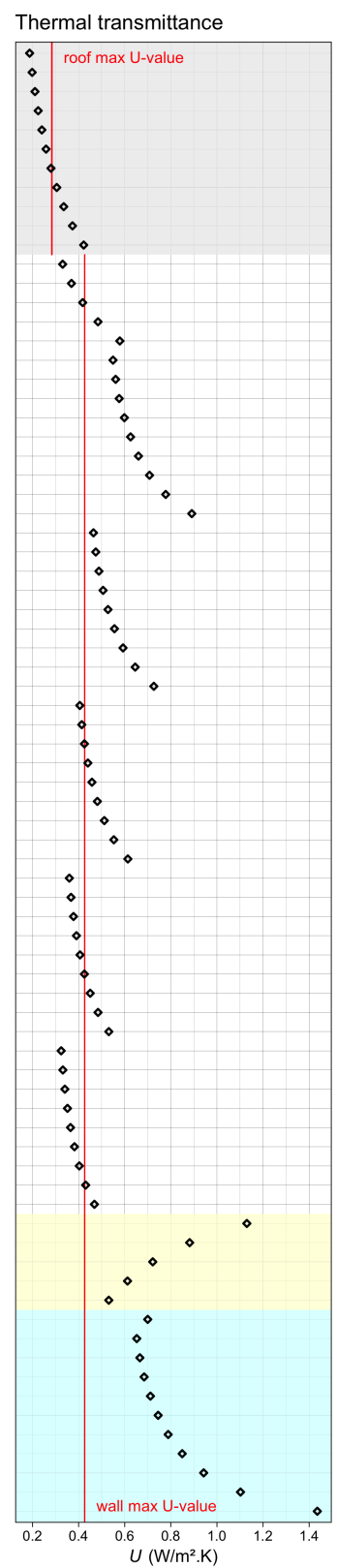

(b)

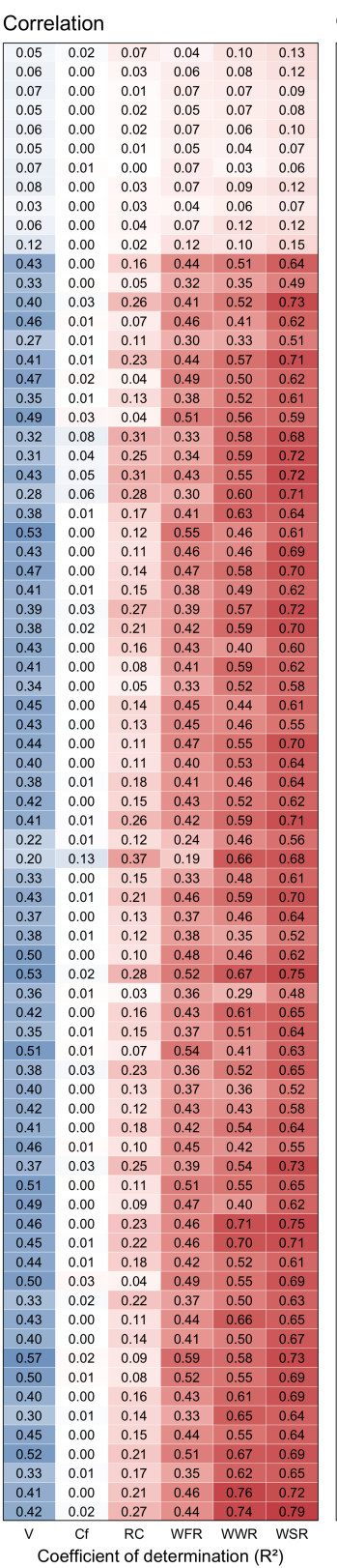

(c)

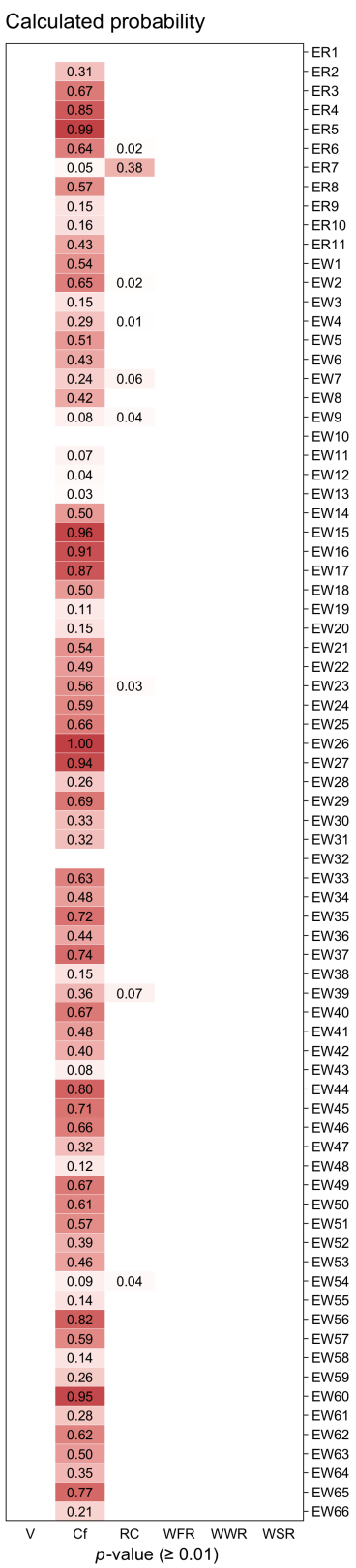

(d)

Fig. 13. a) Buildings' energy consumption $E$ per construction element; b) thermal transmittance $(U$-value); c) coefficient of determination $\left(\mathrm{R}^{2}\right)$; and, d) calculated probability of the geometry-based indexes correlations $(p$-value). In graphs a) and b), the grey background corresponds to roof elements, white to hybrid construction, yellow to warm-framed construction, and blue to cold-framed construction. In graph a), the arithmetic mean of all buildings performance is marked as a vertical red line. In graph b), maximum $U$-value for roofs and walls defined by the Kuwaiti building code for light construction with medium light external color are marked as vertical red lines (MEW, 2010). In graph c) blue color corresponds to positive and red to negative correlation with $E$. In graph d), only the results with $p$-value above or equal to 0.01 are illustrated. In graphs c) and d) the geometry-based indexes are $V$ - volume, $C_{f}$ - shape coefficient, $R C$ - relative compactness, $W F R$ - window-to-floor ratio, $W W R$ - window-to-wall ratio, and $W S R$ - window-to-exterior surface ratio.

It is observable that the energy consumption mean average of each subgroup (black dot) follows the corresponding element $U$-value (black diamond). It is also noticeable, especially in the cold and warm-framed wall types, that the range of each subgroup diminishes as the $U$-value also decreases, thus indicating a decreasing influence of the geometry variables. When comparing different exterior 
wall types with equivalent $U$-values, such as EW41 (hybrid wall) and EW55 (warm-framed wall), or EW53 (warm-framed wall) and EW60 (cold-framed wall), the performance range is similar thus indicating that the position of the insulation in the LSF construction system does not affect the energy consumption in Kuwaiti climate. Comparing the results with the maximum $U$-values for roofs and walls defined by the Kuwaiti 2010 building code for light construction with medium light external color (MEW, 2010), the results show that both roofs and exterior walls may have lower $U$-values without any detriment of the energy consumption. In this work, all the LSF construction systems have low thermal mass and, therefore, only the thermal resistance of the envelope influences the energy consumption of the building. The performance ranges of the 11 roof types are very similar and are influenced by the exterior wall types of the sample.

Considering in Fig 13 ; the intervals $[0,0.2[$ very weak, $[0.2,0.4[$ weak, [0.4, 0.6[ moderate, $[0.6,0.8[$ strong, and $[0.8,1]$ very strong for the correlation scale, it is noticeable that the influence of roof types has none or very weak correlation (positive or negative) with the subgroups energy consumption. As for the exterior walls, the energy consumption shows a weak or moderate positive correlation (shown as blue cells) with the building volume $(V)$, no correlation with $C_{f}-$ the samples did not reject the null hypothesis -, weak to very weak negative correlations (depicted as red cells) with $R C$, and moderate to strong negative correlations with $W F R, W W R$, and $W S R$. Therefore, the building shape does not affect significantly the energy consumption, but the glazing elements contribute positively to the performance, for instance, as the window indexes increase, the energy consumption tends to decrease. Of course, this is valid considering that the windows are modelled to have an exterior shading device activated during the day to avoid solar heat gains, as explained in section 2.4

\section{Conclusion}

This paper presented a generative design approach to evaluate the energy consumption for air-conditioning of LSF villas in Kuwait. The EPSAP algorithm was used to randomly generate a dataset of 6010 geometries with 726 combinations of the construction system. The synthetic dataset was then grouped according to the roof and wall construction elements, and the influence of several geometry-based indexes on the energy consumption of the building was analyzed. It was concluded that:

- roof types do not show significant correlation with the energy consumption $E$, while exterior wall types present weak to moderate positive correlation of $E$ with the $V$, very weak to weak negative correlation of $E$ with the $R C$, moderate to strong negative correlation of $E$ with $W F R, W W R$, and $W S R$ indexes; 
- building shape has a very weak to weak negative correlation with $E$, thus showing that designers are free to explore other building forms without compromising the energy consumption of the building;

- the glazing areas (protected by shadowing mechanisms during the day to prevent solar heat gains) contribute to the reduction of the energy demand for air-conditioning, as $W F R$, $W W R$, and $W S R$ indexes have moderate to strong negative correlations - the higher the window's area the better the energy consumption;

- the position of the insulation layer does not influence the energy consumption of the LSF building (there is no significant difference among hybrid, warm, and cold-framed exterior walls with similar thermal transmittance), and only the thermal resistance of the construction elements really influences the energy performance - the higher the level of insulation, the lower is the energy consumption of the LSF building; and,

- the results show that regulatory maximum $U$-values might decrease further for both roofs and exterior walls of light construction, as the energy performance might still improve.

\section{Acknowledgements}

The authors are grateful to Balthazar Aroso for providing information on the LSF System $\mathrm{B}(\mathrm{A})^{\mathrm{a}}$ and for authorizing the use of the LSF schematics and the elements cross-sections presented in Fig. 3 and 4 .

The research presented has been developed under the Energy for Sustainability Initiative of the University of Coimbra (UC).

Funding: This work has been financed by the Portuguese Foundation for Science and Technology (FCT) and by the European Regional Development Fund (FEDER) through COMPETE 2020 - Operational Program for Competitiveness and Internationalization (POCI) in the framework of the research projects PCMs4Buildings (PTDC/EMS-ENE/6079/2014 and POCI-01-0145-FEDER016750) and Ren4EEnIEQ (PTDC/EMS-ENE/3238/2014, POCI-01-0145-FEDER-016760, and LISBOA01-0145-FEDER-016760). Eugénio Rodrigues acknowledges the support provided by FCT, under Postdoc grant SFRH/BPD/99668/2014.

\section{FCT COMPETE 1202020}

\section{References}

¡Typical Appliance Energy Use and Costs (2014). URL: http://www.nnppd.com/billing/appliance_energy_use/ Appliance_Monthly_Use_Chart.pdf 
EnergyPlus Version 8.7 Documentation: Input Output Reference Manual (2016a). URL: https://energyplus.net.

Estimating Appliance and Home Electronic Energy Use (2016b). URL: https://energy.gov/energysaver/ estimating-appliance-and-home-electronic-energy-use.

Balthazar Aroso Arquitectos Lda (2017). URL: http://www.balthazar-aroso.com/en/

Urbimagem LSF System B(A) ${ }^{\mathrm{a}}$ (2017). URL: http://www.urbimagem.com/

Al-ajmi, F. F., \& Hanby, V. I. (2008). Simulation of energy consumption for Kuwaiti domestic buildings. Energy and Buildings, 40, 1101-1109. doi doi:10.1016/j.enbuild.2007.10.010

Al-Mumin, A., Khattab, O., \& Sridhar, G. (2003). Occupants' behavior and activity patterns influencing the energy consumption in the Kuwaiti residences. Energy and Buildings, 35, 549-559. doi doi:10.1016/S0378-7788(02) 00167-6.

Alotaibi, S. (2011). Energy consumption in Kuwait: Prospects and future approaches. Energy Policy, 39 , 637-643. doi doi:10.1016/j.enpol.2010.10.036

AlSanad, S., Gale, A., \& Edwards, R. (2011). Challenges of sustainable construction in Kuwait investigating level of awareness of Kuwait stakeholders. World Academy of Science, Engineering and Technology, 59, $2197-2204$.

Alshalfan, S. (2013). The right to housing in Kuwait: An urban injustice in a socially just system. Technical Report. URL: http://eprints.1se.ac.uk/55012/

Ameer, B., \& Krarti, M. (2016). Impact of subsidization on high energy performance designs for Kuwaiti residential buildings. Energy and Buildings, 116, 249-262. doi:doi:10.1016/j.enbuild.2016.01.018

ASHRAE (2013a). ANSI/ASHRAE Standard 62.1-2013: Ventilation for Accceptable Indoor Air Quality. Technical Report 62.1-2013 ANSI/ASHRAE.

ASHRAE (2013b). Chapter 18 - Nonresidential cooling and heating load calculations. In 2013 ASHRAE Handbook: Fundamentals. American Society of Heating, Refrigerating and Air-Conditioning Engineers, Inc.

Burstrand, H. (1998). Light-gauge steel framing leads the way to an increased productivity for residential housing. Journal of Constructional Steel Research, 46, 183-186. doi doi:10.1016/S0143-974X(98)00141-2

Caldas, L. G. (2008). Generation of energy-efficient architecture solutions applying GENE_ARCH: An evolutionbased generative design system. Advanced Engineering Informatics, 22, 59-70. doi doi:10.1016/j.aei.2007.08.012.

Cerezo, C., Sokol, J., AlKhaled, S., Reinhart, C., Al-Mumin, A., \& Hajiah, A. (2017). Comparison of four building archetype characterization methods in urban building energy modeling (UBEM): A residential case study in Kuwait City. Energy and Buildings, 154, 321-334. doi:doi:10.1016/j.enbuild.2017.08.029

Cerezo, C., Sokol, J., Reinhart, C., \& Al-mumin, A. (2015). Three Methods for Characterizing Building Archetypes in Urban Energy Simulation - A case study in Kuwait City. In Proceedings of BS2015: 14th Conference of International Building Performance Simulation Association, Hyderabad, India,7-9 December. URL: http://web. mit.edu/SustainableDesignLab/publications/BS2015_KuwaitModel.pdf

Chakrabarti, A., Shea, K., Stone, R. B., Cagan, J., Campbell, M. I., Hernandez, N. V., \& Wood, K. L. (2011). Computer-Based Design Synthesis Research: An Overview. Journal of Computing and Information Science in Engineering, 11, 021003-10. doi doi:10.1115/1.3593409

Doran, S., \& Gorgolewski, M. (2002). U-values for light steel-frame construction. BREPress.

Duarte, J. P. (2005). A discursive grammar for customizing mass housing: the case of Siza's houses at Malagueira. Automation in Construction, 14, 265-275. doi doi:10.1016/j.autcon.2004.07.013.

Evins, R. (2013). A review of computational optimisation methods applied to sustainable building design. Renewable and Sustainable Energy Reviews, 22, 230-245. doi doi:10.1016/j.rser.2013.02.004.

Evola, G., \& Marletta, L. (2014). The effectiveness of PCM wallboards for the energy refurbishment of lightweight buildings. Energy Procedia, 62, 13-21. doi doi:10.1016/j.egypro.2014.12.362 
Evola, G., Marletta, L., \& Sicurella, F. (2013). A methodology for investigating the effectiveness of PCM wallboards for summer thermal comfort in buildings. Building and Environment, 59, 517-527. doi doi:10.1016/j.buildenv. 2012.09 .021

Gorgolewski, M. (2007). Developing a simplified method of calculating U-values in light steel framing. Building and Environment, 42, 230-236. doi doi:10.1016/j.buildenv.2006.07.001

Höglund, T., \& Burstrand, H. (1998). Slotted steel studs to reduce thermal bridges in insulated walls. Thin-Walled Structures, 32, 81-109.

ISO 6946:2007 (2007). Building components and building elements - Thermal resistance and thermal transmittance

- Calculation method.

Jalal, S. J., \& Bani, R. K. (2017). Orientation modeling of high-rise buildings for optimizing exposure/transfer of insolation, case study of Sulaimani, Iraq. Energy for Sustainable Development, 41, 157-164. doi doi:10.1016/j.esd. 2017.09 .003

Kalay, Y. E. (1999). Performance-based design. Automation in Construction, 8, 395-409.

Kalay, Y. E. (2004). Architecture's New Media: Principles, Theories, and Methods of Computer-Aided Design. Cambridge, Massachusetts: MIT Press.

Kaynakli, O. (2012). A review of the economical and optimum thermal insulation thickness for building applications. Renewable and Sustainable Energy Reviews, 16, 415-425. doi doi:10.1016/j.rser.2011.08.006

Kendrick, C., Ogden, R., Wang, X., \& Baiche, B. (2012). Thermal mass in new build UK housing: A comparison of structural systems in a future weather scenario. Energy and Buildings, 48, 40-49. doi doi:10.1016/j.enbuild.2012. 01.009

Krarti, M. (2014). Analysis of economical and environmental benefits of promoting energy efficiency in buildings: Case Study Kuwait. URL: http://www.unece.org/fileadmin/DAM/energy/se/pdfs/gee21/projects/others/ Kuwait.pdf

Krarti, M. (2015). Evaluation of large scale building energy efficiency retrofit program in Kuwait. Renewable and Sustainable Energy Reviews, 50, 1069-1080. doi doi:10.1016/j.rser.2015.05.063.

Machairas, V., Tsangrassoulis, A., \& Axarli, K. (2014). Algorithms for optimization of building design: A review. Renewable and Sustainable Energy Reviews, 31, 101-112. doi doi:10.1016/j.rser.2013.11.036.

Mandilaras, I., Stamatiadou, M., Katsourinis, D., Zannis, G., \& Founti, M. (2013). Experimental thermal characterization of a Mediterranean residential building with PCM gypsum board walls. Building and Environment, 61, 93-103. doi doi:10.1016/j.buildenv.2012.12.007

Martins, C., Santos, P., \& Simões da Silva, L. (2016). Lightweight steel-framed thermal bridges mitigation strategies: A parametric study. Journal of Building Physics, 39, 342-372. doi:doi:10.1177/1744259115572130

Merrell, P., Schkufza, E., Li, Z., Agrawala, M., \& Koltun, V. (2011). Interactive Furniture Layout Using Interior Design Guidelines. In SIGGRAPH 2011, August 20111 (pp. 1-10).

MEW (2010). Energy Conservation Program: Code of Practice. Technical Report MEW/R-6/2010 Ministry of Electricity and Water of Kuwait.

Oxman, R. (2008). Performance-based Design: Current Practices and Research Issues. International Journal of Architectural Computing, 06, 1-17. doi doi:10.1260/147807708784640090

Park, H. (2013). Dynamic Thermal Modeling of Electrical Appliances for Energy Management of Low Energy Buildings. Technical Report NNT:2013CERG0683 Université de Cergy Pontoise.

Rodrigues, E., Amaral, A. R., Gaspar, A. R., \& Gomes, Á. (2015). How reliable are geometry-based building indices as thermal performance indicators? Energy Conversion and Management, 101, 561-578. doi doi:10.1016/ j.enconman.2015.06.011 
Rodrigues, E., Fernandes, M., Soares, N., Gaspar, A. R., Gomes, Á., \& Costa, J. J. (2018). Dataset of generated and evaluated kuwaiti public authority for housing welfare building design program with lightweight steel framed construction elements. URL: https://goo.gl/iixkcx. doi doi:10.6084/m9.figshare.5507983

Rodrigues, E., Gaspar, A., \& Gomes, Á. (2013a). An approach to the multi-level space allocation problem in architecture using a hybrid evolutionary technique. Automation in Construction, 35, 482-498. doi:doi:10.1016/j. autcon.2013.06.005

Rodrigues, E., Gaspar, A., \& Gomes, Á. (2013b). An evolutionary strategy enhanced with a local search technique for the space allocation problem in architecture, part 1: Methodology. Computer Aided-Design, 45, 887-897. doi doi:10.1016/j.cad.2013.01.001

Rodrigues, E., Gaspar, A., \& Gomes, Á. (2013c). An evolutionary strategy enhanced with a local search technique for the space allocation problem in architecture, part 2: Validation and performance tests. Computer Aided-Design, 45, 898-910. doi doi:10.1016/j.cad.2013.01.003

Rodrigues, E., Gaspar, A., \& Gomes, Á. (2014a). Automated approach for design generation and thermal assessment of alternative floor plans. Energy and Buildings, 81, 170-181. doi doi:10.1016/j.enbuild.2014.06.016

Rodrigues, E., Gaspar, A., \& Gomes, Á. (2014b). Improving thermal performance of floor plan designs using a sequential design variables optimization procedure. Applied Energy, 132, 200-215. doi doi:10.1016/j.apenergy. 2014.06 .068

Rodrigues, L. T., Gillott, M., \& Tetlow, D. (2013d). Summer overheating potential in a low-energy steel frame house in future climate scenarios. Sustainable Cities and Society, 7, 1-15. doi doi:10.1016/j.scs.2012.03.004.

Rodriguez-Ubinas, E., Arranz, B., Sánchez, S. V., \& González, F. J. N. (2013). Influence of the use of PCM drywall and the fenestration in building retrofitting. Energy and Buildings, 65, 464-476. doi:doi:10.1016/j.enbuild.2013. 06.023

Sage-Lauck, J. S., \& Sailor, D. J. (2014). Evaluation of phase change materials for improving thermal comfort in a super-insulated residential building. Energy and Buildings, 79, 32-40. doi doi:10.1016/j.enbuild.2014.04.028

Santos, P., Martins, C., \& Simões da Silva, L. (2014). Thermal performance of lightweight steel-framed construction systems. Metallurgical Research \& Technology, 111, 329-338. doi doi:10.1051/metal/2014035

Santos, P., Simões da Silva, L., \& Ungureanu, V. (2012). Energy Efficiency of Light-weight Steel-framed Buildings. European Convention for Constructional Steelwork (ECCS), Technical Committee 14 - Sustainability \& EcoEfficiency of Steel Construction.

Singh, V., \& Gu, N. (2012). Towards an integrated generative design framework. Design Studies, 33, $185-207$. doi doi:10.1016/j.destud.2011.06.001

Soares, N., Bastos, J., Dias Pereira, L., Soares, A., Amaral, A. R., Asadi, E., Rodrigues, E., Lamas, F. B., Monteiro, H., Lopes, M. A., \& Gaspar, A. R. (2017a). A review on current advances in the energy and environmental performance of buildings towards a more sustainable built environment. Renewable and Sustainable Energy Reviews, 77, 845-860. doi doi:10.1016/j.rser.2017.04.027.

Soares, N., Costa, J. J., Gaspar, A. R., \& Santos, P. (2013). Review of passive PCM latent heat thermal energy storage systems towards buildings' energy efficiency. Energy and Buildings, 59, 82-103. doi doi:10.1016/j.enbuild. 2012.12 .042

Soares, N., Gaspar, A. R., Santos, P., \& Costa, J. J. (2014). Multi-dimensional optimization of the incorporation of PCM-drywalls in lightweight steel-framed residential buildings in different climates. Energy and Buildings, 70, 411-421. doi doi:10.1016/j.enbuild.2013.11.072

Soares, N., Reinhart, C. F., \& Hajiah, A. (2017b). Simulation-based analysis of the use of PCM-wallboards to reduce cooling energy demand and peak-loads in low-rise residential heavyweight buildings in Kuwait. Building 
Simulation, 10, 481-495. doi doi:10.1007/s12273-017-0347-2.

Soares, N., Santos, P., Gervásio, H., Costa, J., \& Simões da Silva, L. (2017c). Energy efficiency and thermal performance of lightweight steel-framed (LSF) construction: A review. Renewable and Sustainable Energy Reviews, 78, 194-209. doi doi:10.1016/j.rser.2017.04.066.

Veljkovic, M., \& Johansson, B. (2006). Light steel framing for residential buildings. Thin-Walled Structures, 44, 1272-1279. doi doi:10.1016/j.tws.2007.01.006

Wonka, P., Wimmer, M., Sillion, F., \& Ribarsky, W. (2003). Instant architecture. ACM Transactions on Graphics, 22, 669. doi doi:10.1145/882262.882324.

Wu, M. H., Ng, T. S., \& Skitmore, M. R. (2016). Sustainable building envelope design by considering energy cost and occupant satisfaction. Energy for Sustainable Development, 31, 118-129. doi doi:10.1016/j.esd.2015.12.003. 